\title{
Adiponectin Exerts Peripheral Inhibitory Effects on the Mouse Gastric Smooth Muscle through the AMPK Pathway
}

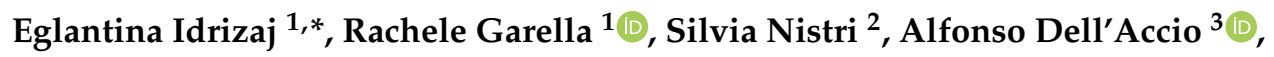 \\ Emanuele Cassioli ${ }^{4}\left({ }^{\oplus}\right.$, Eleonora Rossi ${ }^{4}{ }^{\circ}$, Giovanni Castellini ${ }^{4}$, Valdo Ricca ${ }^{4}{ }^{\circ}$, \\ Roberta Squecco $^{1, *}$ and Maria Caterina Baccari ${ }^{1}$ \\ 1 Department of Experimental \& Clinical Medicine, Section of Physiological Sciences, University of Florence, \\ 50134 Firenze, Italy; rachele.garella@unifi.it (R.G.); mcaterina.baccari@unifi.it (M.C.B.) \\ 2 Department of Experimental \& Clinical Medicine, Research Unit of Histology \& Embryology, \\ University of Florence, 50139 Firenze, Italy; silvia.nistri@unifi.it \\ 3 Department of Biomedical, Experimental \& Clinical Sciences "Mario Serio", University of Florence, \\ 50134 Firenze, Italy; alfonso.dellaccio@unifi.it \\ 4 Department of Health Sciences, Psychiatry Unit, University of Florence, 50134 Firenze, Italy; \\ emanuele.cassioli@unifi.it (E.C.); e.rossi@unifi.it (E.R.); giovanni.castellini@unifi.it (G.C.); \\ valdo.ricca@unifi.it (V.R.) \\ * Correspondence: eglantina.idrizaj@unifi.it (E.I.); roberta.squecco@unifi.it (R.S.); \\ Tel.: +39-055-275-1629 (E.I.); +39-055-275-1632 (R.S.)
}

Received: 20 November 2020; Accepted: 15 December 2020; Published: 17 December 2020

\begin{abstract}
Some adipokines, such as adiponectin (ADPN), other than being implicated in the central regulation of feeding behavior, may influence gastric motor responses, which are a source of peripheral signals that also influence food intake. The present study aims to elucidate the signaling pathways through which ADPN exerts its actions in the mouse gastric fundus. To this purpose, we used a multidisciplinary approach. The mechanical results showed that ADPN caused a decay of the strip basal tension, which was abolished by the nitric oxide (NO) synthesis inhibitor, $\mathrm{L}-\mathrm{N}^{\mathrm{G}}$-nitro arginine (L-NNA). The electrophysiological experiments confirmed that all ADPN effects were abolished by L-NNA, except for the reduction of $\mathrm{Ca}^{2+}$ current, which was instead prevented by the inhibitor of AMP-activated protein kinase (AMPK), dorsomorphin. The activation of the AMPK signaling by ADPN was confirmed by immunofluorescence analysis, which also revealed the ADPN R1 receptor (AdipoR1) expression in glial cells of the myenteric plexus. In conclusion, our results indicate that ADPN exerts an inhibitory action on the gastric smooth muscle by acting on AdipoR1 and involving the AMPK signaling pathway at the peripheral level. These findings provide novel bases for considering AMPK as a possible pharmacologic target for the potential treatment of obesity and eating disorders.
\end{abstract}

Keywords: adiponectin; cell signaling; AMPK; AdipoR1; gastric fundus; mechanical activity; cell excitability

\section{Introduction}

Adipokines are molecules secreted by the white adipose tissue and are involved in a wide range of functions through endocrine, paracrine, and autocrine mechanisms [1,2]. Among the different functions, some adipokines are implicated in the central regulation of feeding behavior and also affect gastrointestinal motor phenomena [3], which are known to be peripheral signals that are able to influence food intake through the gut-brain axis [4]. 
In this regard, we recently observed that adiponectin (ADPN), an adipocytes-released peptide that plays a role in the regulation of food intake at the central level, was also able to exert a neuromodulatory inhibitory effect in strips from the mouse gastric fundus [5]. In agreement with the mechanical studies [5], our preliminary electrophysiological investigations indicated that the hormone also depressed gastric smooth muscle cell (SMC) excitability [6]. Different ion channels are present in the gastric smooth muscle playing key roles in the modulation of SMC excitability and contraction. Particularly, L-type calcium channels have been reported in both fundal [6,7] and antral gastric strips isolated from rats [8] as well as in antral myocytes of guinea pigs [9]. Notably, voltage-dependent L-type $\mathrm{Ca}^{2+}$ channels are the backbone of excitation-contraction coupling in the gut $[10,11]$. However, gastrointestinal SMCs express additional T-type calcium channels that may contribute as a factor in delivery of $\mathrm{Ca}^{2+}$ to the contractile apparatus in some cells [12]. Many $\mathrm{K}^{+}$channels are also expressed in gastrointestinal SMCs such as delayed rectifier fast activating $\alpha$-dendrotoxin ( $\alpha$-DTX)-sensitive $\mathrm{K}^{+}$channels $(\mathrm{Kv})$ [13-16], large-conductance $\mathrm{Ca}^{2+}$-activated $\mathrm{K}^{+}$channels $(\mathrm{BK})[17,18]$ and small conductance $\mathrm{Ca}^{2+}$-activated $\mathrm{K}^{+}$ channels (SK) $[19,20]$.

ADPN exerts its effects mainly through the activation of two transmembrane receptors, AdipoR1 and AdipoR2, whose expression has been revealed in the brain as well as in a variety of mammalian peripheral tissues [21], including the gastrointestinal tract [5,22]. The biological effects of ADPN are related to the expression of tissue-specific receptors and to the different signaling pathways engaged. In this regard, in the vascular system, the hormone initiates the AMP-activated protein kinase (AMPK)-mediated nitric oxide synthase (NOS) activation, leading to an increase of nitric oxide (NO) production [23]. Notably, AMPK, an enzyme characterized by a tissue-specific mechanism of activation [24], acts at central level (hypothalamus) to control appetite and body weight, making it an important pharmacologic target for the potential treatment of obesity and eating disorders $[25,26]$.

In addition to the central anorexigenic effect of ADPN [27], a peripheral mechanism that could strengthen such action can be represented right by the stomach wall distension, which is a well-known satiety signal, favored by the gastric smooth muscle cell relaxation induced by the hormone. In this view, it could be important to elucidate the signaling pathways involved in the effects of ADPN at the gastrointestinal level, but no data are present in the literature. Accordingly, the aim of this study was to investigate the possible mechanisms through which ADPN exerts its inhibitory effects at the gastric level.

\section{Results}

\subsection{L-NNA Prevents the Mechanical Inhibitory Effect of ADPN on the Gastric Fundus}

At basal tension and in the presence of guanethidine, the addition of carbachol $(\mathrm{CCh}, 1 \mu \mathrm{M})$ to the bath medium ( $n=8$ strips) elicited a rapidly arising contraction (mean amplitude $1.2 \mathrm{~g} \pm 0.2 \mathrm{~g}$ ), which persisted until washout. As previously observed in CCh-precontracted strips [5], $20 \mathrm{nM}$ ADPN caused, after 1-2 min of contact time, a progressive and long-lasting decay of the basal tension (mean amplitude $0.16 \mathrm{~g} \pm 0.03 \mathrm{~g}, n=8)$ (Figure 1) which was not affected by tetrodotoxin (TTX, $1 \mu \mathrm{M})(p>0.05$, $n=2)$, thus indicating that the hormone action occurs on the smooth muscle. The chosen dose of $\operatorname{ADPN}(20 \mathrm{nM})$ is that previously reported to be effective in gastric preparations $[5,6]$.

In the presence of the NO synthesis inhibitor, $\mathrm{L}_{-\mathrm{N}^{G}}$-nitro arginine (L-NNA, $200 \mu \mathrm{M}$ ), the addition of $20 \mathrm{nM}$ ADPN to the bath medium ( $n=6$ strips) had no longer influence on the strip basal tension (Figure 1) $(p>0.05)$, suggesting that the effects of the hormone are mediated by NO.

Based on the present observations, we first performed electrophysiological experiments to investigate the role of NO in the effects of ADPN on the gastric SMCs. 

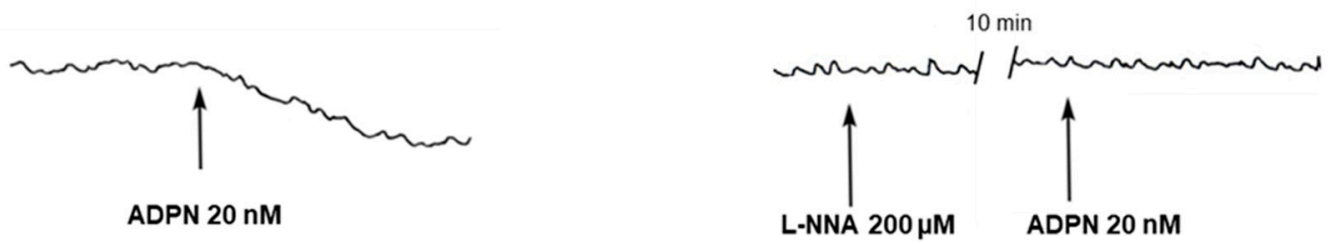

Figure 1. Lack of effects of adiponectin (ADPN) on carbachol (CCh)-precontracted gastric strips in the presence of $\mathrm{L}^{-\mathrm{N}^{\mathrm{G}}}$-nitro arginine (L-NNA). Typical tracing (left hand panel) showing the long-lasting and slight (note the magnitude of the amplification) decay of the strip basal tension caused by $20 \mathrm{nM}$ ADPN. Such an effect, already appreciable within 1 min of contact time, persists up to 30 min (longer time not observed). When ADPN is added to the bath medium $15 \mathrm{~min}$ after the NO synthesis inhibitor L-NNA $(200 \mu \mathrm{M})$, it is no longer able to induce the decay of the strip basal tension (right hand panel). Traces obtained from two different preparations.

\subsection{L-NNA Hampers the Effects of ADPN on the Resting Membrane Potential and on the Membrane Passive} Properties of SMCS

To better investigate the effect of ADPN in the presence of L-NNA observed in the mechanical experiments, we firstly conducted electrophysiological experiments on the resting membrane potential (RMP) of SMCs.

The acute addition of ADPN to the bath solution caused a statistically significant hyperpolarization (Figure 2A,C, Table 1), which is quite in accordance with the decay of the basal tension observed in the mechanical experiments. Such hyperpolarization was already appreciable 1-3 min following the hormone application and reached the most negative (hyperpolarized) value after about 15 min (Figure 2A). In the presence of L-NNA (Figure 2B,C, Table 1), ADPN was no longer able to induce any hyperpolarization, suggesting the NO involvement in the alteration of membrane potential.

Table 1. Passive membrane properties and normalized ion current amplitude (current response evoked by the $+50 \mathrm{mV}$ pulse) of gastric fundus SMCs in the different conditions.

\begin{tabular}{|c|c|c|c|c|c|}
\hline & $\mathrm{Cm}(\mathrm{pF})$ & Gm (pS) & RMP (mV) & $\mathrm{I}_{\mathrm{K}}(\mathrm{pA} / \mathrm{pF})$ & $\mathrm{I}_{\mathrm{Ca}}(\mathrm{pA} / \mathrm{pF})$ \\
\hline CTRL & $\begin{array}{c}13.5 \pm 1.8 \\
(n=52)\end{array}$ & $\begin{array}{c}0.009 \pm 0.002 \\
(n=52)\end{array}$ & $\begin{array}{c}-47.2 \pm 5.0 \\
(n=50)\end{array}$ & $\begin{array}{c}17.1 \pm 3.7 \\
(n=30)\end{array}$ & $\begin{array}{c}-20.3 \pm 6.0 \\
(n=20)\end{array}$ \\
\hline ADPN & $\begin{array}{c}24.7 \pm 2.2 * \\
(n=17)\end{array}$ & $\begin{array}{c}0.0175 \pm 0.002 \\
(n=16)\end{array}$ & $\begin{array}{c}-59.4 \pm 3.9 * \\
(n=16)\end{array}$ & $\begin{array}{c}23.9 \pm 2.1 * \\
(n=9)\end{array}$ & $\begin{array}{c}-10.1 \pm 2 * \\
(n=7)\end{array}$ \\
\hline L-NNA & $\begin{array}{c}12.3 \pm 3.9 \# \\
(n=18)\end{array}$ & $\begin{array}{c}0.0072 \pm 0.001 \\
(n=18)\end{array}$ & $\begin{array}{c}-47.0 \pm 5.1 \# \\
(n=17)\end{array}$ & $\begin{array}{c}8.3 \pm 2.9^{*}, \# \\
(n=10)\end{array}$ & $\begin{array}{c}-24.9 \pm 4.1 \# \\
(n=7)\end{array}$ \\
\hline L-NNA + ADPN & $\begin{array}{c}10.9 \pm 3.1 \# \\
(n=18)\end{array}$ & $\begin{array}{c}0.0078 \pm 0.001 \\
(n=18)\end{array}$ & $\begin{array}{c}-46.6 \pm 4.3 \# \\
(n=17)\end{array}$ & $\begin{array}{c}7.8 \pm 1.8^{*}, \# \\
(n=10)\end{array}$ & $\begin{array}{c}-10.0 \pm 2.3 *, \S \\
(n=7)\end{array}$ \\
\hline DORS & $\begin{array}{c}9.5 \pm 6.7 \# \\
(n=16)\end{array}$ & $\begin{array}{c}0.005 \pm 0.001 \\
(n=13)\end{array}$ & $\begin{array}{c}-39.2 \pm 5.9 \# \\
(n=14)\end{array}$ & $\begin{array}{c}17.6 \pm 3.0 \# \\
(n=7)\end{array}$ & $\begin{array}{c}-27.3 \pm 4.1 \# \\
(n=6)\end{array}$ \\
\hline DORS + ADPN & $\begin{array}{c}8.5 \pm 2.4 \# \\
(n=16)\end{array}$ & $\begin{array}{c}0.007 \pm 0.002 \\
(n=13)\end{array}$ & $\begin{array}{c}-35.7 \pm 4.9 \# \\
(n=14)\end{array}$ & $\begin{array}{c}17.8 \pm 2.8 \# \\
(n=7)\end{array}$ & $\begin{array}{c}-25 \pm 2.3 \# \\
(n=6)\end{array}$ \\
\hline
\end{tabular}

One-way ANOVA with Bonferroni's post hoc test was used for multiple comparisons. ${ }^{*}, p<0.05$ significant difference from CTRL; \#, $p<0.05$ significant difference from ADPN; $\S, p<0.05$ significant difference from L-NNA. $n$ represents the number of SMCs used (10 mice). Values are means \pm SD. 


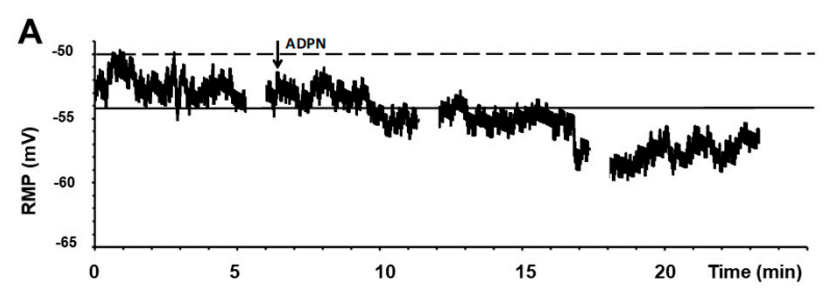

B
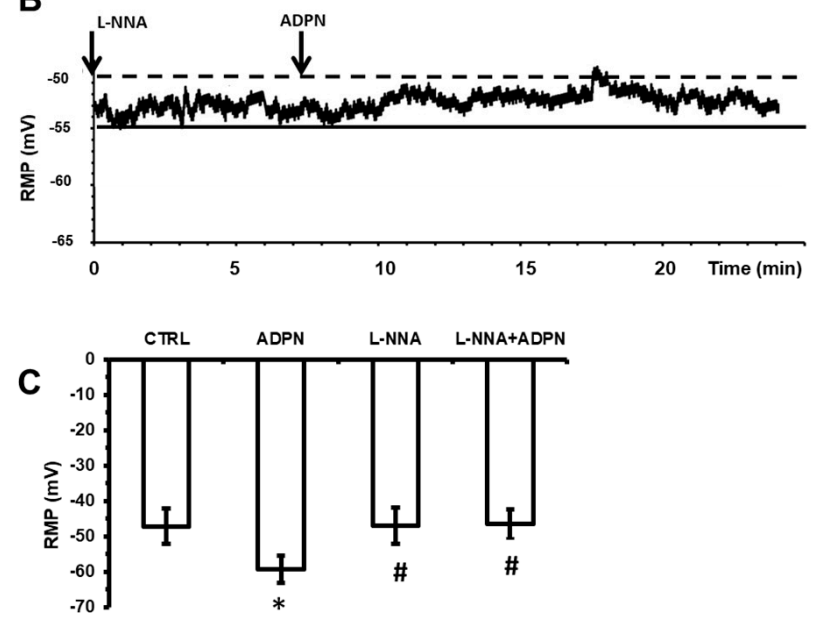
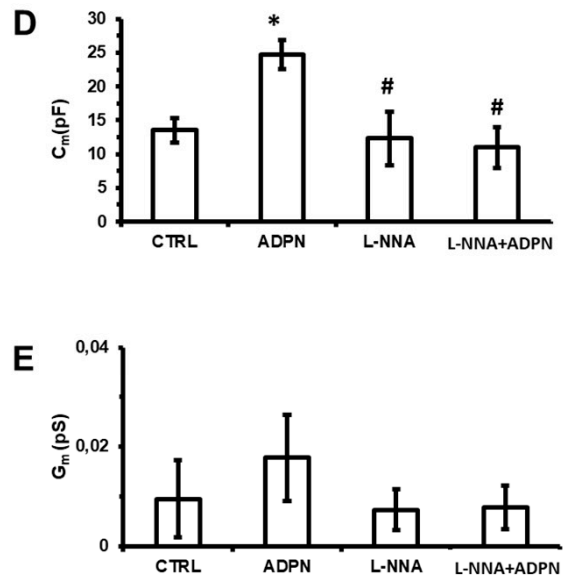

Figure 2. The effects of ADPN on the resting membrane potential and on passive membrane properties of a gastric smooth muscle cell (SMC) are prevented by L-NNA. (A) Typical tracing of resting membrane potential (RMP) from a single gastric SMC. Asynchronous and irregular waves of resting membrane potential recorded in basal condition and almost 15 min after ADPN (20 nM) addition (arrow). ADPN induced a persistent hyperpolarization occurring right after about 2-3 min from its application. (B) Typical tracing of RMP recorded in the presence of L-NNA (arrow) and almost 15 min after ADPN $(20 \mathrm{nM})$ addition (arrow). (A,B) Continuous line is the mean value of resting membrane potential and dashed line is the maximal value of the peak waves. (C) Bar charts representing the effects of ADPN alone or in its concomitant presence of L-NNA on the RMP. (D) Bar charts showing the effect of ADPN and ADPN+L-NNA on the cell capacitance $(\mathrm{Cm})$, index of cell surface, of the SMCs. (E) Bar charts showing the effect of ADPN and ADPN+L-NNA on the membrane conductance $(\mathrm{Gm})$, index of membrane permeability, of the SMCs. For any parameter, data are evaluated in control condition (CTRL), 15 min after adiponectin addition to the bath solution (ADPN) and in the concomitant presence of L-NNA and ADPN (L-NNA+ADPN). One-way ANOVA with Bonferroni's post hoc test was used for multiple comparisons. ${ }^{*}, p<0.05$ vs. control; $\#, p<0.05$ vs. ADPN. Values are means \pm SD. Mean values are listed in Table 1.

Then, the effect of the hormone in the presence of L-NNA was investigated also on the passive membrane properties of the SMC. As observed in our preliminary report [6], ADPN (20 nM) induced a significant increase of the cell capacitance $(\mathrm{Cm})$ compared to the control, whereas the membrane conductance $(\mathrm{Gm})$ was reduced. Notably, all of the effects of ADPN on Cm (Figure 2D, Table 1) and Gm (Figure 2E, Table 1) were prevented by L-NNA. These data confirm that ADPN was able to affect the SMC membrane properties, suggesting that the remodeling of the cell surface and of its resting permeability involve the NO pathway.

\subsection{Effects of ADPN on the Ion Currents in the Presence of L-NNA}

\subsubsection{Effects of ADPN on the Different Types of Voltage-Dependent Outward $\mathrm{K}^{+}$Currents}

First of all, we evaluated the effects of ADPN on $\mathrm{K}^{+}$channels of the SMCs, which are supposed to be mostly implicated in the regulation of the RMP. The acute addition of ADPN was able to cause an increase of $\mathrm{I}_{\mathrm{K}}$ compared to control, as observed also in our preliminary study [6]. To clarify the 
different types of the $\mathrm{K}^{+}$channel mostly involved in the effects of the hormone, we here operated a pharmacological dissection of the overall $\mathrm{I}_{\mathrm{K}, \mathrm{TOT}}$, according to the previously published procedure [28]. $\mathrm{I}_{\mathrm{K}, \mathrm{TOT}}$ (Figure $3 \mathrm{~A}$ ) was elicited by a voltage pulse protocol of stimulation in the modified bath control solution containing $\mathrm{BaCl}_{2}$, 4-aminopyridine (4-AP), TTX, nifedipine and heptanol (see Materials and Methods). By this system, we were consistently able to distinguish, in control condition, the fast activating $\alpha$-dendrotoxin $\left(\alpha\right.$-DTX)-sensitive $\mathrm{I}_{\mathrm{Kv}}$, the large conductance $\mathrm{Ca}^{2+}$-activated $\mathrm{K}^{+}$current that was Iberiotoxin (IbTx) sensitive, namely BK current $\left(\mathrm{I}_{\mathrm{BK}}\right)$, and the slowly activating chromanol (Chr)-sensitive $\mathrm{I}_{\mathrm{Ks}}$ (Figure 3(Ba,Bb-Da,Db)). After ADPN addition, we could clearly observe an increase in $\mathrm{I}_{\mathrm{Kv}}$ and $\mathrm{I}_{\mathrm{Ks}}$ amplitudes (Figure $3(\mathrm{Ba}, \mathrm{Bd}, \mathrm{Da}, \mathrm{Db})$ ). Thus, we can assess that the outward $\mathrm{K}^{+}$current increase induced by ADPN was mostly due to the potentiation of the $\mathrm{K}_{\mathrm{v}}$ and $\mathrm{K}_{\mathrm{s}}$ currents. In contrast, BK resulted reduced by ADPN treatment (Figure 3(Ca, Cb)).
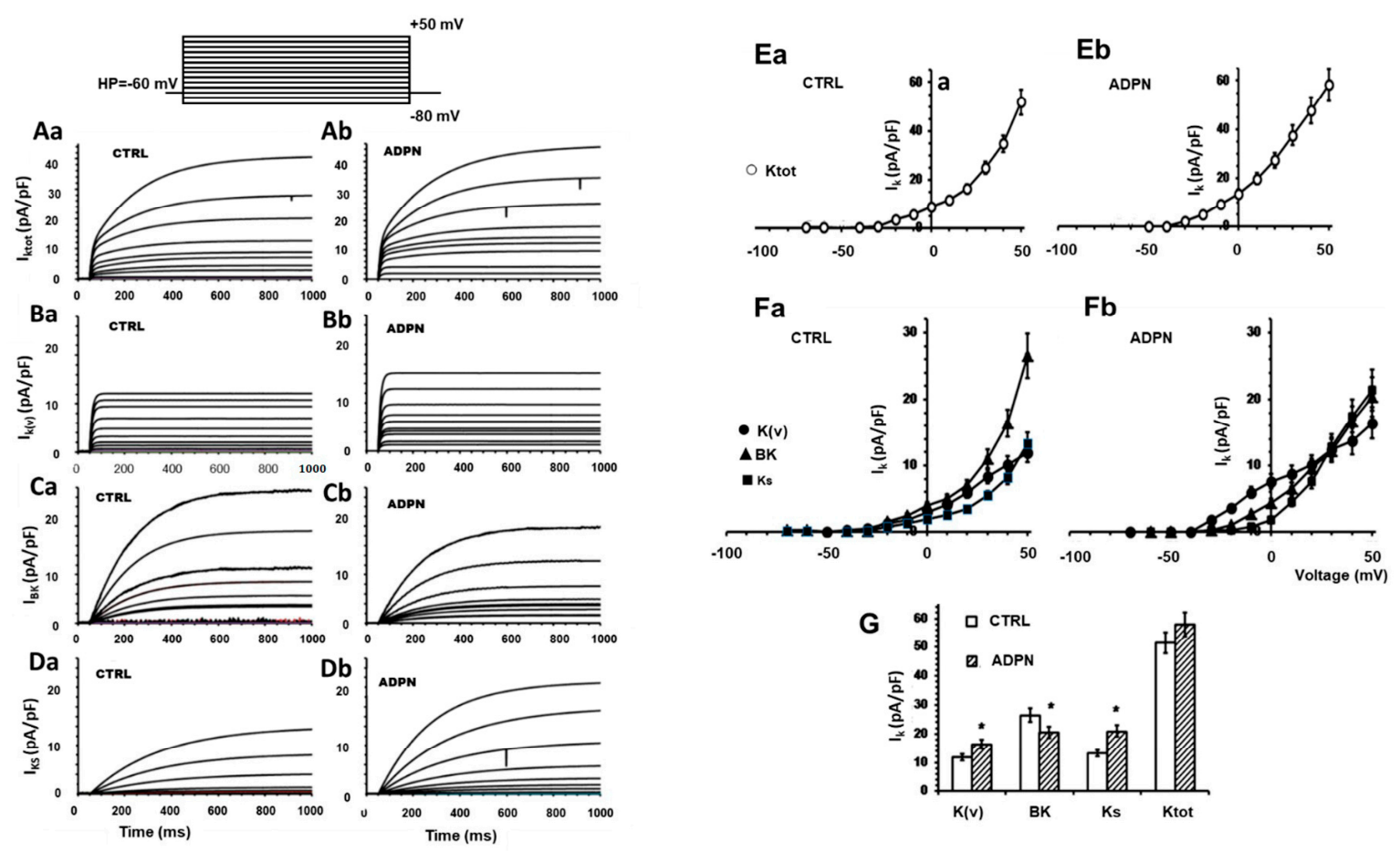

Figure 3. Effects of ADPN on the different voltage-dependent $\mathrm{K}^{+}$currents in an SMC from the gastric fundus. (Aa,Ab)Total outward $\mathrm{K}^{+}$currents traces, elicited by voltage steps from -80 to $+50 \mathrm{mV}$ (holding potential $(\mathrm{HP})=-60 \mathrm{mV})$ in nifedipine $(10 \mu \mathrm{M})$ containing solution, in control condition (Aa), and in the presence of ADPN $20 \mathrm{nM}(\mathbf{A b})$. Current values are normalized to cell capacitance. The pharmacological dissection allowed us to systematically distinguish three kinds of K+ currents: IKv $(\mathbf{B a}, \mathbf{B b})$; IBK $(\mathbf{C a}, \mathbf{C b})$; and IKs $(\mathbf{D a}, \mathbf{D b})$. Current values are normalized to cell capacitance. (Ea,Eb) I-V plots related to IK,TOT in CTRL (Ea) and in the presence of ADPN (Eb). (Fa,Eb) I-V plots related to IKV, IBK, and IKs, in CTRL conditions (Fa) and in the presence of ADPN (Fb). The continuous lines through the experimental data represent the fitted Boltzmann function. Current values are normalized to cell capacitance. Statistical significance is not depicted in the figure for clarity. $(G)$ Bar charts representing the amplitude of $\mathrm{K}+$ current for IK,TOT, IKV, IBK, and IKs, in CTRL conditions and in the presence of ADPN. Comparison of the maximal current values recorded at $+50 \mathrm{mV} ;{ }^{*} p<0.05$ of ADPN vs. CTRL. All of the data are mean values \pm SEM. In each experimental condition, data are from CTRL $n=30$ cells, $\mathrm{ADPN} n=9$ cells ( 5 mice). 
To better evaluate the general trend of this event, we calculated the I-V relationship related to all of the experiments done, reporting the normalized mean current maximal amplitude for any voltage step applied (Figure 3(Ea,Eb,Fa,Fb)). The analysis of the I-V plot confirmed that ADPN treatment enhanced the fast and low-threshold activated $\mathrm{I}_{\mathrm{Kv}}$ and the slow and high-threshold activated $\mathrm{I}_{\mathrm{Ks}}$, thus enabling the compensation of the fast and slow changes of the resting membrane potential. In contrast, the $\mathrm{Ca}^{2+}$-dependent $\mathrm{K}^{+}$currents with an intermediate voltage threshold was mainly reduced. The voltage threshold of activation of the different currents was $-40 \pm 5,-30 \pm 5$ and $-20 \pm 4 \mathrm{mV}$ for $\mathrm{I}_{\mathrm{Kv}}, \mathrm{I}_{\mathrm{BK}}$, and $\mathrm{I}_{\mathrm{Ks}}$, respectively (Figure 3G). However, in a lower percentage of cells (less than $8 \%$ ), we observed an increase in $\mathrm{I}_{\mathrm{K}, \mathrm{TOT}}$ current due to BK (not shown) as also reported for vascular tissues [29]. Thus, we can conclude that in gastric SMC, ADPN increases the outward $\mathrm{K}^{+}$ current, mainly enhancing $\mathrm{Kv}$ and $\mathrm{K}_{\mathrm{s}}$ currents.

\subsubsection{Effects of ADPN on the Different Types of Voltage-Dependent Inward $\mathrm{Ca}^{2+}$ Current}

As already observed by Idrizaj et al., 2019 [6], ADPN also influences calcium channels by inducing a reduction of $\mathrm{I}_{\mathrm{Ca}}$ amplitude. In the present study, we intended to clarify if ADPN could affect a specific type of $\mathrm{Ca}^{2+}$ current that is, $\mathrm{T}$ - and/or L-type $\mathrm{Ca}^{2+}$ currents $\left(\mathrm{I}_{\mathrm{Ca}, \mathrm{T}}\right.$ and $\left.\mathrm{I}_{\mathrm{Ca}, \mathrm{L}}\right)$. Thus, we applied a suitable pulse protocol of stimulation starting from a holding potential $(\mathrm{HP})=-80 \mathrm{mV}$ for evoking the $\mathrm{Ca}^{2+}$ currents using the high-tetraethylammonium (TEA) solution in the bath (see Materials and Methods section). When this type of experiment was performed in the presence of nifedipine $(10 \mu \mathrm{M})$ to block L-type $\mathrm{Ca}^{2+}$ channels, we could observe a residual low voltage activated current with a rapid and transient time course (peak time, $t_{p}=5.5 \pm 0.5 \mathrm{~ms}$ ), suggesting the occurrence of $\mathrm{I}_{\mathrm{Ca}, \mathrm{T}}$ (Figure $4(\mathrm{Ba})$ ). The addition of ADPN decreased the maximal size of $\mathrm{I}_{\mathrm{Ca}, \mathrm{T}}$ slightly affecting its time to peak $\left(t_{p}=5.8 \pm 0.5 \mathrm{~ms}\right)$ and negatively shifting the maximal activation from -25 to $-30 \mathrm{mV}$ (Figure 4(Bb)), Table 2). By subtracting the current traces obtained in the presence of nifedipine from the total currents (data not shown), we obtained the L-type $\mathrm{Ca}^{2+}$ channel contribution alone (Figure 4(Ca)): we observed high-voltage-activated current traces with a slow decay and with the maximum amplitude reached in $22.7 \pm 2 \mathrm{~ms}$ evoked by a $0-\mathrm{mV}$ step pulse. Once again, the addition of ADPN decreased the size of $\mathrm{I}_{\mathrm{Ca}, \mathrm{L}}$ (Figure $4(\mathrm{Cb})$ ) apparently without altering its time to peak (Table 2), but shifting the voltage value of the pulse required to evoke the maximal current amplitude from 0 to $10 \mathrm{mV}$ (Figure 4(Da,Db)).

Table 2. Boltzmann parameters of $\mathrm{I}_{\mathrm{Ca}, \mathrm{T}}$ and $\mathrm{I}_{\mathrm{Ca}, \mathrm{L}}$ activation and inactivation obtained in gastric SMCs in control condition (CTRL) and after adiponectin (ADPN) addition.

\begin{tabular}{ccccc}
\hline & \multicolumn{2}{c}{$\mathbf{I}_{\mathbf{C a}, \mathbf{T}}$} & \multicolumn{2}{c}{$\mathbf{I}_{\mathbf{C a}, \mathbf{L}}$} \\
\hline Parameters & CTRL & ADPN & CTRL & ADPN \\
\hline $\mathrm{I}_{\mathrm{Ca}, \mathrm{p}} / \mathrm{C}_{\mathrm{m}}(\mathrm{pA} / \mathrm{pF})$ & $1.7 \pm 0.2$ & $0.5 \pm 0.1^{* * *}$ & $9.42 \pm 0.6$ & $5.2 \pm 0.4^{* *}$ \\
$\mathrm{G}_{\mathrm{m}} / \mathrm{C}_{\mathrm{m}}(\mathrm{pS} / \mathrm{pF})$ & $18 \pm 5$ & $5.5 \pm 9^{* * *}$ & $46 \pm 5.1$ & $32 \pm 3.8^{* *}$ \\
$\mathrm{~V}_{\mathrm{thr}}(\mathrm{mV})$ & $-54.8 \pm 2$ & $-53.0 \pm 2$ & $-50.2 \pm 3$ & $-48.7 \pm 3$ \\
$\mathrm{~V}_{\mathrm{p}}(\mathrm{mV})$ & $-25.1 \pm 2$ & $-30.2 \pm 1.6^{* *}$ & $0.5 \pm 0.07$ & $10.2 \pm 1^{* * *}$ \\
$\mathrm{~V}_{\mathrm{a}}(\mathrm{mV})$ & $-42.1 \pm 3$ & $-40.0 \pm 2$ & $-18.1 \pm 2$ & $-10.2 \pm 2^{* * *}$ \\
$\mathrm{k}_{\mathrm{a}}(\mathrm{mV})$ & $7.2 \pm 0.4$ & $7.1 \pm 0.5$ & $7.6 \pm 0.3$ & $8.1 \pm 0.4$ \\
$\mathrm{~V}_{\text {rev }}(\mathrm{mV})$ & $76.5 \pm 6$ & $80.1 \pm 7$ & $79.4 \pm 6$ & $81.7 \pm 7$ \\
$\mathrm{~V}_{\mathrm{h}}(\mathrm{mV})$ & $-64.7 \pm 6$ & $-64.8 \pm 6$ & $-51 \pm 4$ & $-53 \pm 5$ \\
$\mathrm{k}_{\mathrm{h}}(\mathrm{mV})$ & $4.5 \pm 0.5$ & $4.3 \pm 0.4$ & $7.5 \pm 0.5$ & $7.4 \pm 0.5$ \\
$\mathrm{t}_{\mathrm{p}}(\mathrm{ms})$ & $5.5 \pm 0.5$ & $5.8 \pm 0.5$ & $22.7 \pm 2$ & $21.8 \pm 3$ \\
\hline
\end{tabular}

ADPN decreases the normalized maximum peak size of the specific $\mathrm{I}_{\mathrm{Ca}, \mathrm{p}} / \mathrm{C}_{\mathrm{m}}$ and the related $\mathrm{G}_{\mathrm{m}} / \mathrm{C}_{\mathrm{m}}$ for both $\mathrm{T}$ and $\mathrm{L}$ type $\mathrm{Ca}^{2+}$ current; moreover, it shifts the voltage values that elicits the maximal current in the I-V plots (Vp) and affects the $\mathrm{I}_{\mathrm{Ca}, \mathrm{L}}$ and $\mathrm{I}_{\mathrm{Ca}, \mathrm{T}}$ kinetics, influencing the Boltzmann parameters of activation (Va and ka) and inactivation (Vh and $\mathrm{Kh}$ ). The subscript $\mathrm{p}$ indicates the peak value, $\mathrm{V}_{\text {thr }}$ is voltage threshold, $\mathrm{V}_{\text {rev }}$, is the apparent reversal potential, and $t_{p}$ is peak time at the voltage eliciting the maximal current amplitude. All data are mean values $\pm S E M$ ${ }^{* *}$ and ${ }^{* * *}$ indicate $p<0.01$, and $p<0.001$ ADPN vs. CTRL data, respectively (Student's $t$-test). Data are from CTRL $n=20$ cells, ADPN $n=7$ cells, ( 5 mice). 

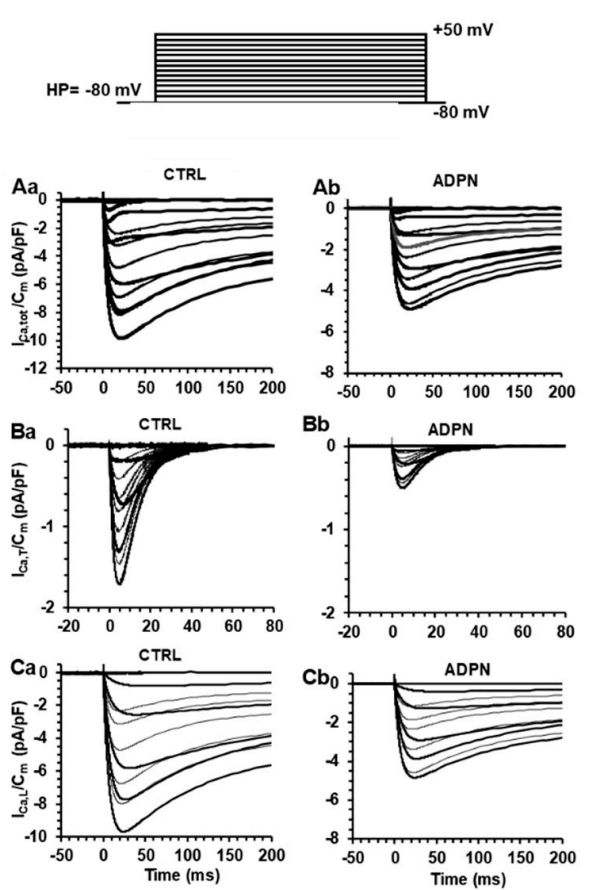

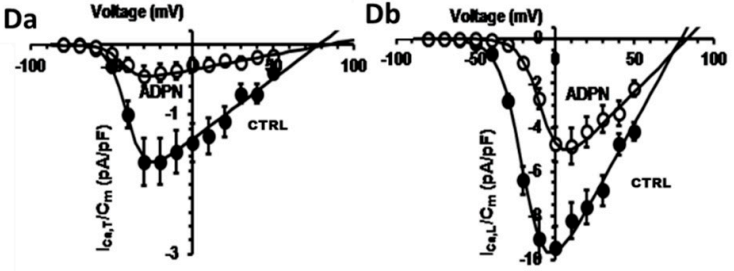

Ea

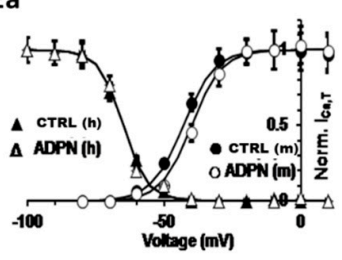

Eb

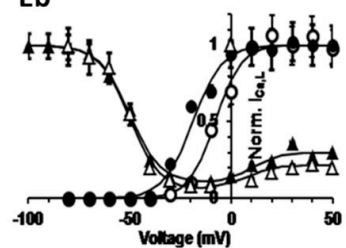

Figure 4. Effects of ADPN on the voltage-dependence of T- and L-type $\mathrm{Ca}^{2+}$ channels activation. $(\mathbf{A a}, \mathbf{A b})$ Current traces of total inward $\mathrm{Ca}^{2+}$ currents $\left(\mathrm{I}_{\mathrm{Ca}}\right)$ recorded in control SMC $(\mathbf{A a})$ and in the presence of $\operatorname{ADPN}(\mathbf{A b})$. Current values are normalized to cell capacitance. $(\mathbf{B a}, \mathbf{B b})$ Representative time course of T-type $\mathrm{Ca}^{2+}$ currents $\left(\mathrm{I}_{\mathrm{Ca}, \mathrm{T}}\right)$ recorded in the presence of nifedipine from a control cell $(\mathbf{B a})$ and after ADPN addition $(\mathbf{B b})$. $(\mathbf{C a}, \mathbf{C b})$ Time course showing L-type $\mathrm{Ca}^{2+}$ currents $\left(\mathrm{I}_{\mathrm{Ca}, \mathrm{L}}\right)$ recorded in the high TEA-Ca ${ }^{2+}$ solution from a control cell (Ca) and after ADPN addition (Cb). Only the first $200 \mathrm{~ms}$ of the pulse are depicted. (Da,Db) I-V plots related to $\mathrm{I}_{\mathrm{Ca}, \mathrm{T}}(\mathbf{D a})$ and $\mathrm{I}_{\mathrm{Ca}, \mathrm{L}}(\mathbf{D b})$ in control (CTRL, filled circles) and ADPN-treated (ADPN, open circles) SMCs from the gastric fundus. Data are normalized for the mean cell capacitance. The lines through the experimental data are the fit with a Boltzmann function. (Ea,Eb) Steady-state activation and inactivation analysis for $\mathrm{I}_{\mathrm{Ca}, \mathrm{T}}(\mathbf{E a})$ and $\mathrm{I}_{\mathrm{Ca}, \mathrm{L}}(\mathbf{E b})$. Effect of ADPN on $\mathrm{I}_{\mathrm{CaT}}$ and $\mathrm{I}_{\mathrm{Ca}, \mathrm{L}}$ activation (open circles, $\mathrm{m}$ ) with respect to control (filled circles, m); lack of effects on inactivation (CTRL, filled triangles, h; ADPN, open triangles, h). Note the U-shaped inactivation curve at positive potentials for $\mathrm{I}_{\mathrm{Ca}, \mathrm{L}}$ that is depressed in ADPN-treated cells. Current values are normalized to cell capacitance. All data are mean values \pm SEM Statistical significance is not depicted in the figure for clarity but is reported for the various Boltzmann parameters in Table 2. Data are from CTRL $n=20$ cells, ADPN $n=7$ cells, ( 5 mice).

To better evaluate the general behavior of the phenomenon, we calculated the I-V relationship related to all the experiments done, reporting the normalized mean $\mathrm{I}_{\mathrm{Ca}}$ maximal amplitude for any voltage step applied (Figure $4(\mathrm{Da}, \mathrm{Db})$ ). The evaluation of the current voltage dependence was performed on $\mathrm{I}_{\mathrm{Ca}, \mathrm{T}}$ and $\mathrm{I}_{\mathrm{Ca}, \mathrm{L}}$ separately in control conditions and under ADPN treatment. Any data point of the plot is the mean value \pm SEM of the peak amplitudes obtained for any voltage step applied in all of the experiments done. Control I-V curves related to $\mathrm{I}_{\mathrm{Ca}, \mathrm{T}}$ and $\mathrm{I}_{\mathrm{Ca}, \mathrm{L}}$ recorded from SMCs of gastric fundus are shown in Figure $4(\mathrm{Da}, \mathrm{Db})$, and the line through the filled symbols represents the fit of a Boltzmann function. Thus, the present experiments show that the reduction of $\mathrm{I}_{\mathrm{Ca}}$ amplitude caused by ADPN addition concerns both the types of current. However, ADPN did not affect the voltage dependence of inactivation neither of T- nor L-type $\mathrm{Ca}^{2+}$ current (Figure $4(\mathrm{Ea}, \mathrm{Eb})$ ). ADPN positively shifted the half-maximal activation voltage value of $\mathrm{I}_{\mathrm{Ca}, \mathrm{T}}$ activation of $5.1 \pm 1 \mathrm{mV}$ and that of $\mathrm{I}_{\mathrm{Ca}, \mathrm{L}}$ of $19.8 \pm 4 \mathrm{mV}$ compared to control. The related Boltzmann parameters with statistical significance are listed in Table 2.

Moreover, it is to note that the inactivation curves did not steadily keep on at zero level at positive potentials but progressively increased causing a sort of U-shaped inactivation curve. This behavior 
may suggest that inactivation was $\mathrm{Ca}^{2+}$-dependent. ADPN depressed this phase, which was probably due to the minor intracellular $\left[\mathrm{Ca}^{2+}\right]_{i}$ as a consequence of the decreased $\mathrm{Ca}^{2+}$ influx through L-type $\mathrm{Ca}^{2+}$ channels.

\subsubsection{L-NNA Prevents the Effect of ADPN on $\mathrm{K}^{+}$Channels but Not on $\mathrm{ca}^{2+}$ Channels}

To elucidate the whole scenario, we tested the effect of ADPN when the NO synthesis was inhibited also on the occurrence of ion currents $\mathrm{I}_{\mathrm{K}}$ and $\mathrm{I}_{\mathrm{Ca}}$. In the present research, we observed that the hormone was no more able to induce the increase of the total $\mathrm{K}^{+}$current outflow in the presence of L-NNA (Figure 5(Ba-Bc),E, Table 1). Typical tracings are shown in Figure 5(Aa,Ab-Da-Dc) for the different conditions. Interestingly, ADPN in the presence of L-NNA continued to reduce $\mathrm{Ca}^{2+}$ entry, especially the early transient phase of the trace with a rapid transient time course (Figure 5(Da-Dc),F, Table 1). Such observation may suggest that, in addition to NO, other signaling effectors could be involved in the mechanism by which ADPN modulates $\mathrm{Ca}^{2+}$ channels in gastric smooth muscle.

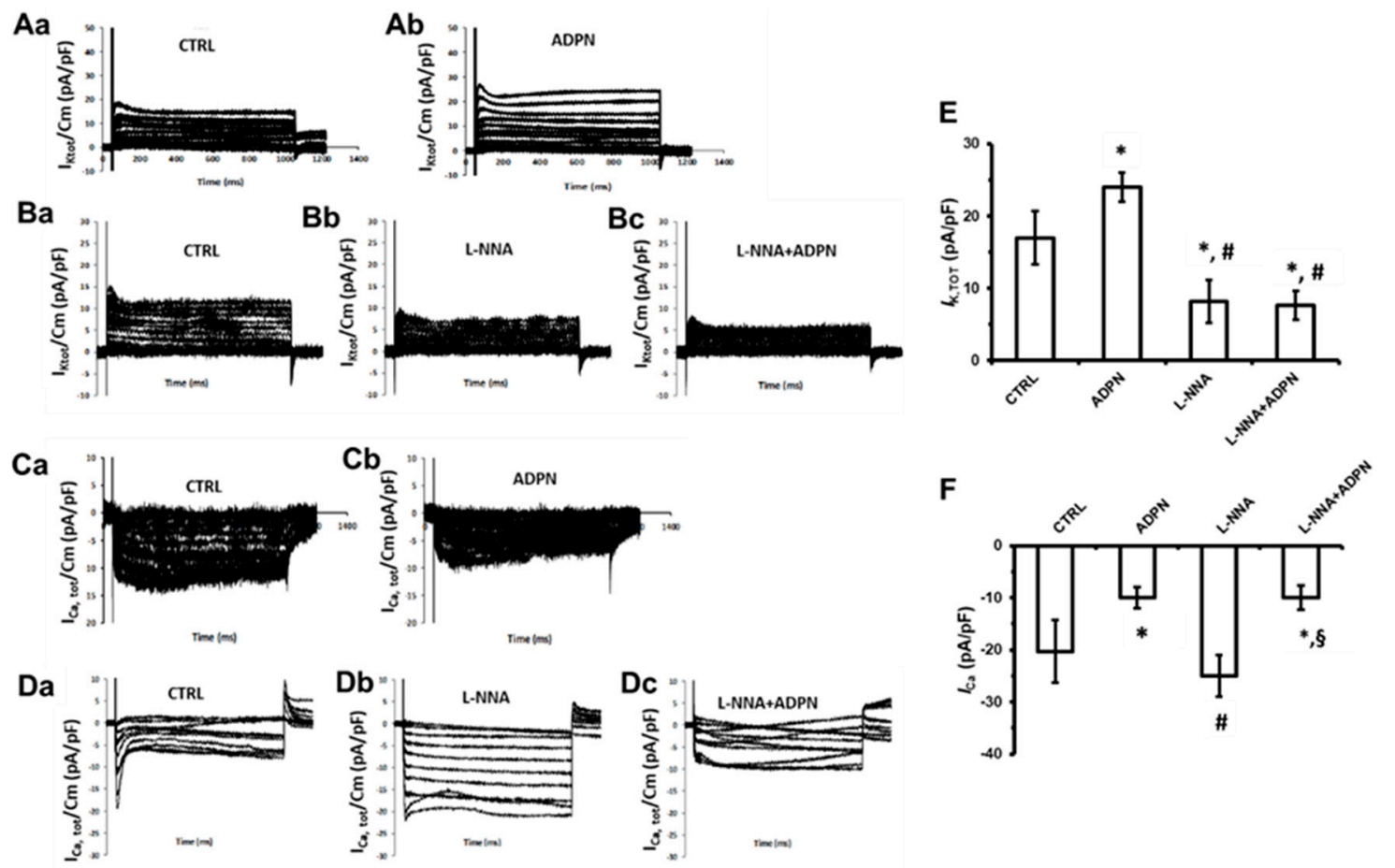

Figure 5. Effects of ADPN on the ion currents in a single SMC in the presence of L-NNA. (Aa,Ab) Typical tracing of total outward $\mathrm{K}^{+}$current recorded in a single control cell (Aa) and after ADPN addition $(\mathbf{A b})$. (Ba-Bc) Typical tracing of total outward $\mathrm{K}^{+}$current recorded in a single control cell (Ba), in L-NNA $(\mathbf{B b})$, and after ADPN addition in the presence of L-NNA $(\mathbf{B c})$. $(\mathbf{C a}, \mathbf{C b})$ Typical tracing of total inward $\mathrm{Ca}^{2+}$ current recorded in a single control cell $(\mathbf{C a})$ and after ADPN addition $(\mathbf{C b})$. (Da-Dc) Typical tracing of total inward $\mathrm{Ca}^{2+}$ current recorded in a single control cell (Da), in L-NNA $(\mathrm{Db})$, and after ADPN addition in the presence of L-NNA (Dc). All current values are normalized to cell capacitance. (E) Bar charts representing the effects of ADPN, L-NNA, and L-NNA+ADPN on the total $\mathrm{K}^{+}$current outflow. (F) Bar charts representing the effects of ADPN, L-NNA, and L-NNA+ADPN on the total $\mathrm{Ca}^{2+}$ current inflow. Bar charts are related to the current amplitude evoked by the $+50 \mathrm{mV}$ step pulse, measured at the end of the stimulus for $\mathrm{K}^{+}$current and at the peak amplitude for $\mathrm{Ca}^{2+}$ currents (Ip, peak current). Data evaluated in control condition (CTRL), $15 \mathrm{~min}$ after adiponectin addition to the bath solution (ADPN) and after adding adiponectin in the presence of L-NNA (L-NNA+ADPN). (E,F) One-way ANOVA with Bonferroni's post hoc test was used for multiple comparisons. ${ }^{*}, p<0.05$ vs. control; \#, $p<0.05$ vs. ADPN;,$~ p<0.05$ vs. L-NNA. Values are means \pm SD. Current mean values are listed in Table 1. 
2.4. Dorsomorphin Hampers the Effects of ADPN on the Electrophysiological Properties and Ion Currents of SMCs

Based on the above observations, we decided to test the involvement of AMP-activated protein kinase (AMPK) that is usually recruited upon AdipoR1 activation [30-33] and is known to mediate NOS activation, leading to an increase of NO production [34-36].

In the presence of dorsomorphin $(10 \mu \mathrm{M})$, which was used to block upstream the AMPK pathway, ADPN was no more able to cause significant alterations of RMP, Cm, or Gm (Figure 6A-C, Table 1). As well, adding ADPN in the presence of dorsomorphin did not alter $\mathrm{K}^{+}$(Figure 6(Ea-Ec)) or $\mathrm{Ca}^{2+}$ current amplitude compared to control (Figure 6(Ga-Gc)). Typical tracings are shown in Figure $6(\mathrm{Da}, \mathrm{Db}-\mathrm{Ga}-\mathrm{Gc})$ for the different conditions. Data were not statistically different compared to control, indicating that ADPN was ineffective in the presence of the AMPK inhibitor.
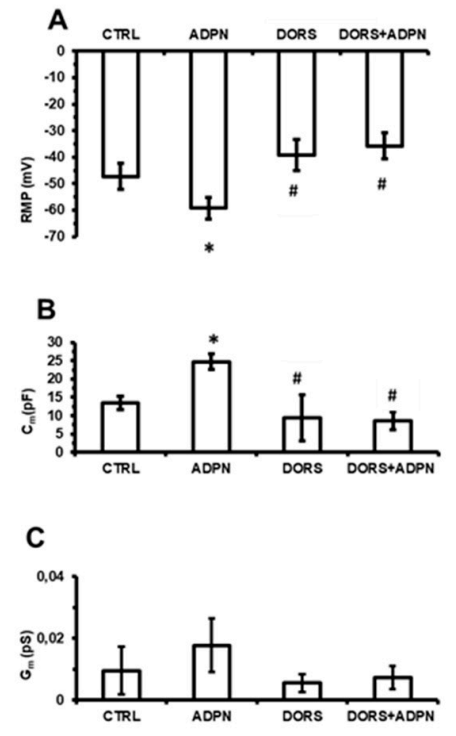
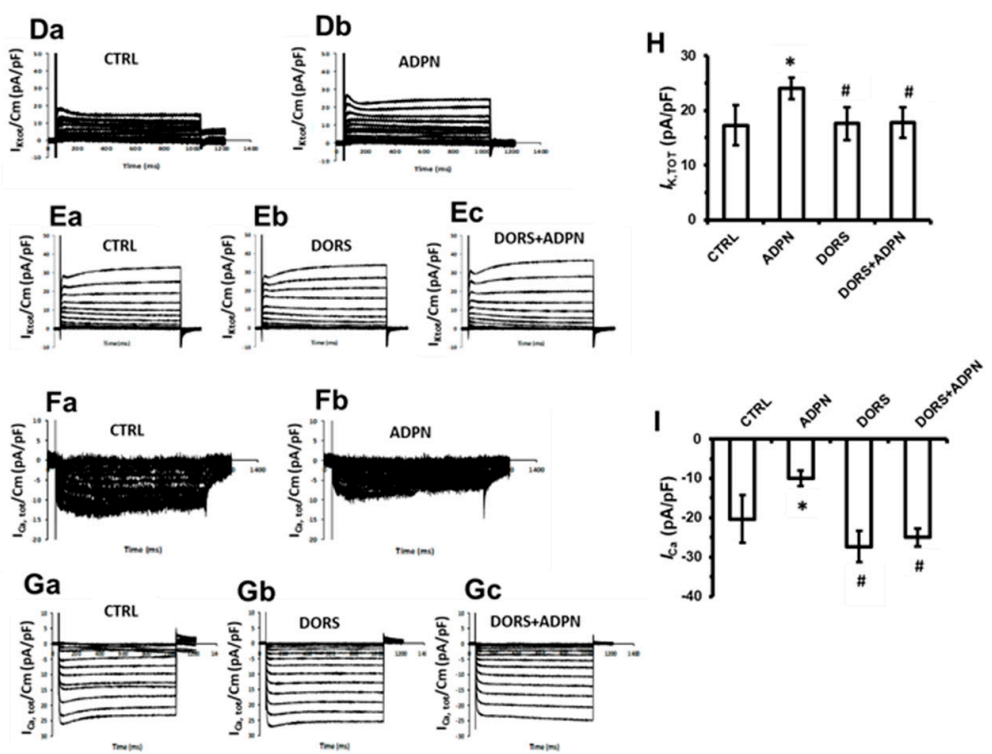

Figure 6. Lack of effects of ADPN on SMC electrophysiological properties and ion currents in the presence of dorsomorphin (DORS). (A) Bar charts showing the effect of ADPN and DORS+ADPN on the resting membrane potential (RMP) of the SMCs. (B) Bar charts showing the effect of ADPN and DORS+ADPN on the cell capacitance $(\mathrm{Cm})$, the index of cell surface, of the SMCs. (C) Bar charts showing the effect of ADPN and DORS+ADPN on the membrane conductance $(\mathrm{Gm})$, the index of membrane permeability, of the SMCs. (Da,Db) Typical tracing of total outward $\mathrm{K}^{+}$current recorded in a single control cell (Da) and after ADPN addition (Db). (Ea-Ec) Typical tracing of total outward $\mathrm{K}^{+}$current recorded in a single control cell (Ea), in dorsomorphin (Eb) and after ADPN addition in the presence of dorsomorphin $(\mathbf{E c})$. (Fa, Fb) Typical tracing of total inward $\mathrm{Ca}^{2+}$ current recorded in a single control cell $(\mathbf{F a})$ and after ADPN addition $(\mathbf{F b})$. (Ga-Gc) Typical tracing of total inward $\mathrm{Ca}^{2+}$ current recorded in a single control cell $(\mathbf{G a})$, in dorsomorphin $(\mathbf{G b})$ and after ADPN addition in the presence of dorsomorphin (Gc). All current values are normalized to cell capacitance. $(\mathrm{H})$ Bar charts representing the effects of ADPN, DORS, and DORS+ADPN on the total $\mathrm{K}^{+}$current outflow. (I) Bar charts representing the effects of ADPN, DORS, and DORS+ADPN on the total calcium current inflow. Bar charts are related to the current amplitude evoked by the $+50 \mathrm{mV}$ step pulse, measured at the end of the stimulus for $\mathrm{K}^{+}$current and in the initial part of the stimulus for $\mathrm{Ca}^{2+}$ currents (Ip, peak current). Data evaluated in control condition (CTRL), $15 \mathrm{~min}$ after adiponectin addition to the bath solution (ADPN), and after adding adiponectin in the presence of dorsomorphin. One-way ANOVA with Bonferroni's post hoc test was used for multiple comparisons. ${ }^{*}, p<0.05$ vs. control; $\#, p<0.05$ vs. ADPN. Current mean values \pm SD are listed in Table 1 . 


\subsection{ADPN Increases AMPK Signaling}

To confirm that ADPN action on gastric preparation involves AMPK activation, we performed Western blotting analysis. We found that ADPN treatment activated the AMPK signaling in the mouse gastric fundus as demonstrated by the significant increase of phosphoAMPK (pAMPK) expression compared to the control samples (Figure 7A). The results obtained by Western blotting were confirmed by immunofluorescence analysis: pAMPK immunostaining appeared increased in the gastric samples from ADPN-treated mice as compared to the controls (Figure 7B), while no difference was detected on AMPK expression (data not shown). Specifically, ADPN induced activation of the AMPK pathway in the glial cells of myenteric plexus as shown by the co-localization of pAMPK and GFAP immunostaining (Figure 7B).
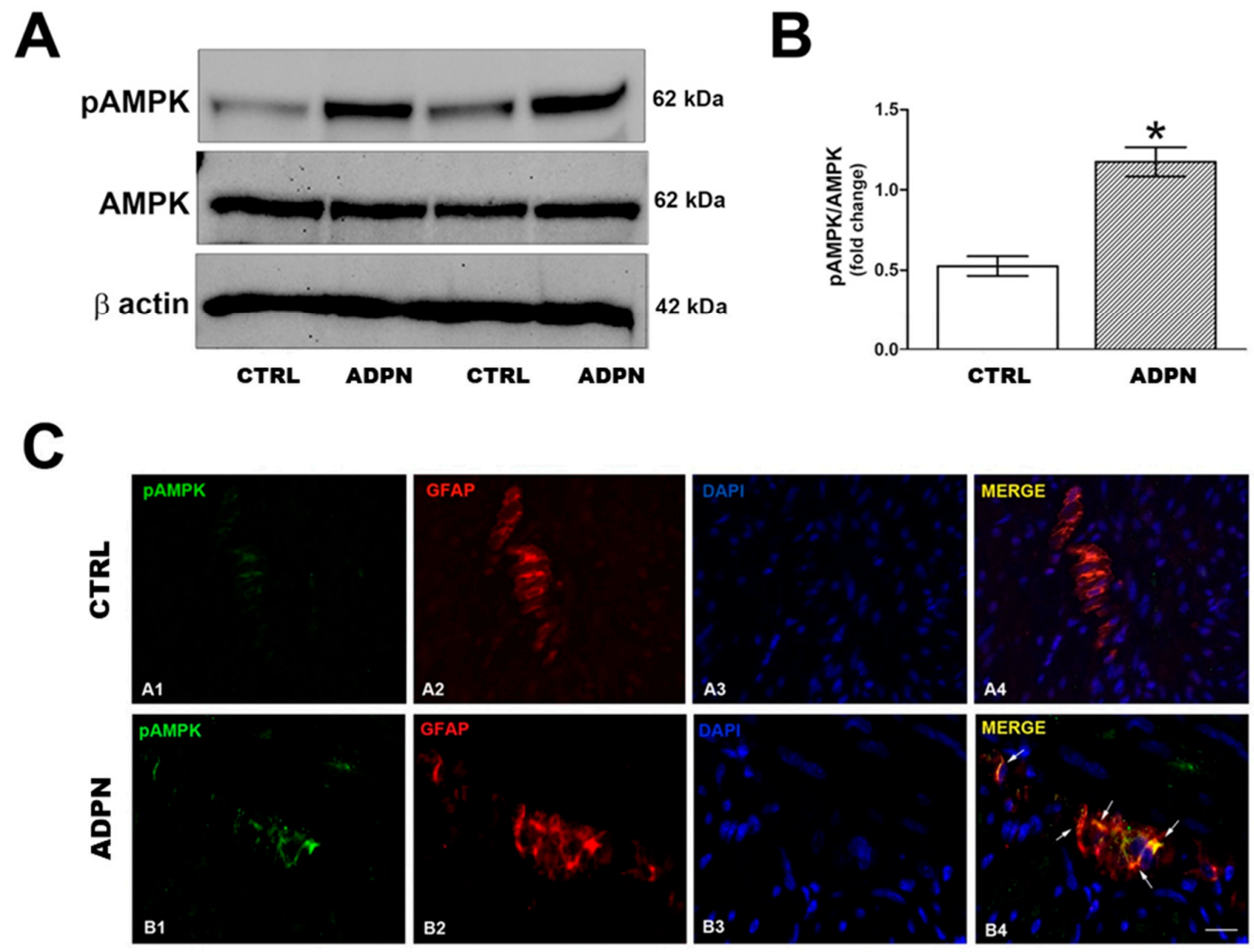

Figure 7. Involvement of AMPK signaling in ADPN action. (A) Effect of ADPN on AMPK signaling pathway in mouse gastric fundus assayed by Western blotting: representative bands from a typical experiment. (B) quantitative analysis. Columns are means \pm SEM. Significance of differences (Student's $t$-test for two independent samples): ${ }^{*} p<0.05$ vs. controls (CTRL). (C) Representative photomicrographs of gastric tissue from control and ADPN-treated mice showing double immunofluorescence labeling. (A1-A4) co-localization of phosphoAMPK (pAMPK) and GFAP in control mice: (A1) pAMPK signal (green channel); (A2) GFAP signal (red channel); (A3) DAPI; (A4) merged images. (B1-B4) co-localization of pAMPK and GFAP in ADPN-treated mice: B1 pAMPK signal (green channel); (B2) GFAP signal (red channel); (B3) DAPI; (B4) merged images. Scale bar: $10 \mu \mathrm{m}$.

\subsection{AdipoR1 Detection}

Several studies indicate that AMPK is usually recruited under AdipoR1 activation [30-33]. Accordingly, we investigated the presence of this receptor in the murine gastric fundus specimen, by performing a dual immunofluorescence labeling. The results obtained revealed that AdipoR1 was expressed by glial cells associated with neurons in the myenteric plexus (Figure 8). In fact, the co-localization of adipoR1 and GFAP immunoreactivities was observed within the myenteric plexus 
(Figure 8(A1-A4)), as showed by the resulting yellow color in the merged image (Figure 8(A4), white arrows), while no co-localization appeared between adipoR1 and the neuronal marker UCH-L1 (Figure 8(B4)). No adipoR1 signal was clearly detected in the gastric smooth musculature (Figure $8(\mathrm{C} 1-\mathrm{C} 4))$.
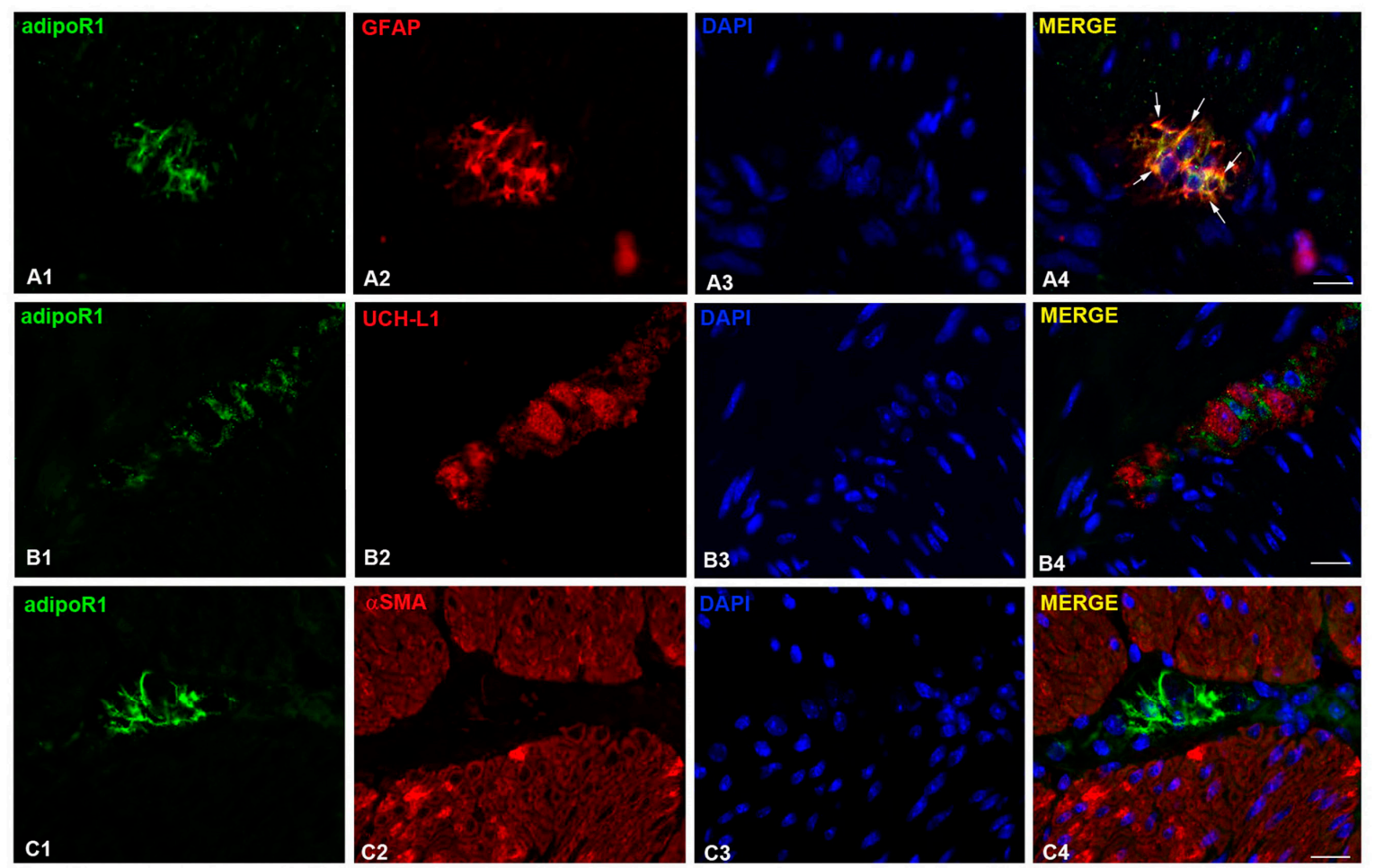

Figure 8. Localization of AdipoR1 in the gastric fundus. Representative photomicrographs of gastric tissue showing double immunofluorescence labeling. (A1-A4) Co-localization of adipoR1 and GFAP: (A1) adipoR1 signal (green channel); (A2) GFAP signal (red channel); (A3) DAPI; (A4) merged images. (B1-B4) Co-localization of adipoR1 and UCH-L1: (B1) adipoR1 signal (green channel); (B2) UCH-L1signal (red channel); (B3) DAPI; (B4) merged images. (C1-C4) Co-localization of adipoR1 and $\alpha \mathrm{SMA}$; (C1) adipoR1 signal (green channel); (C2) $\alpha$ SMA signal (red channel); (C3) DAPI; (C4) merged images. Scale Bars: $10 \mu \mathrm{m}$.

\section{Discussion}

The present study indicates that ADPN exerts its inhibitory action at the gastric smooth muscle level likely acting on AdipoR1 and involving the AMPK/NO pathway.

In addition to the previously reported neuromodulatory action of ADPN on the mechanical responses of the mouse gastric fundus [5], we here observed that the hormone exerts its effects on the smooth muscle. The ability of the NO synthesis inhibitor, L-NNA, to abolish the decay of the basal tension caused by ADPN on gastric strips indicates the involvement of the NO pathway in such effects. Accordingly, NO appears to be a shared target pathway in the hormonal control of gastrointestinal motility $[5,37,38]$, and the ability of ADPN to increase NO synthase expression has been reported in different smooth muscle tissues as in the vascular one [34,39]. In agreement, in the present electrophysiological experiments, we observed that all the effects of ADPN on the membrane passive properties (membrane capacitance and conductance) of gastric SMCs were prevented by L-NNA, underlying the involvement of NO. Moreover, the hyperpolarization induced by ADPN, which is quite in accordance with the decay of the basal tension observed in the mechanical experiments, was also prevented by the NO synthesis inhibitor L-NNA. However, in the present experiments, we observed that in the presence L-NNA, ADPN was no longer able to increase the $\mathrm{K}^{+}$current outflow, but it 
still reduced $\mathrm{Ca}^{2+}$ entry. Such observations strongly indicate that, in addition to NO, other signaling effectors should be involved in the mechanism of action of ADPN on the gastric muscle. In this regard, ADPN has been reported to engage several signaling paths in other smooth muscles $[40,41]$. Among them, AMP-activated protein kinase (AMPK) frequently mediates the effect of the hormone in different organs and tissue [42-45]. Accordingly, in our murine gastric fundus preparations, all the effects of ADPN on RMP and membrane passive proprieties of SMC were prevented by blocking upstream with the inhibitor of AMPK dorsomorphin. This was quite an expected result, since previous papers reported the ability of the hormone to initiate AMPK-mediated NOS activation, thus leading to an increase of NO production [34-36]. Interestingly, in the presence of dorsomorphin, the hormone could not induce any of its effect either on $\mathrm{K}^{+}$or $\mathrm{Ca}^{2+}$ current. This observation strongly points out AMPK involvement in the mechanism of action of ADPN. Indeed, our results indicate that ADPN leads to an enhanced $\mathrm{K}^{+}$outflow by increasing NO production through AMPK activation. In contrast, the reduction of $\mathrm{Ca}^{2+}$ influx is probably due to the AMPK-induced activation of other signaling effectors different from NO. Further studies are necessary to better investigate on the other possible signaling paths activated by AMPK, through which ADPN may modulate $\mathrm{Ca}^{2+}$ channels on the gastric smooth muscle.

The involvement of the AMPK pathway in the mechanism of action of ADPN is further supported by the Western blotting and immunofluorescence results: ADPN treatment significantly increased pAMPK expression in the glial cells associated with neurons in the myenteric plexus of the mouse gastric fundus. Moreover, the presence of AdipoR1 in our specimens, prevalently expressed by glial cells in the myenteric plexus, is in keeping with the involvement of the AMPK pathway, since its recruitment is largely proven in this receptor activation [30-33]. Based on our overall results, we therefore propose that ADPN, activating AdipoR1 on the glial cells, leads to NO production via the AMPK/NOS axis. $\mathrm{NO}$, as a gaseous molecule, can easily diffuse from glial to nearby smooth muscle cells, so influencing their electrophysiological properties. Accordingly, enteric glial cells have been reported to play an important role in the regulation of gastrointestinal motility [46], even if the mechanisms behind this effect need to be elucidated. A representative summary scheme of our hypothesis based on the present results is shown in the Figure 9. Our research designates AMPK as a key mediator of ADPN effects at the gastric level, offering the first direct evidence that the hormone exerts its inhibitory effects, mainly through the AMPK-NO pathway leading to muscle relaxation. The ability of ADPN to induce muscle relaxation leads to an increased gastric wall distension. From a physiological point of view, this can represent an additional peripheral satiety signal [47]. In fact, gastric motor changes represent well-known peripheral factors that are able to send signals to the central structures involved in the regulation of food intake [48]. Thus, we speculated that the here-observed peripheral inhibitory effects induced by ADPN through the activation of AMPK are part of a control system aimed to regulate food intake, which might concur to suppress feeding behavior. Accordingly, acting at the central level (hypothalamus), AMPK controls appetite and body weight [26], making it an important pharmacologic target for the potential treatment of obesity and eating disorders. In this study, we observed the involvement of this path for the first time at the peripheral level in gastric preparations, suggesting that satiety signals originating in diverse regions actually engage the same effectors, strengthening a common aim.

In conclusion, our results support the physiological relevance of ADPN as a part of the multifarious hormonal circuits that coordinate energy homeostasis and food intake, acting at central and peripheral levels. These observations could provide novel bases for the opening of new considerations in the search of a possible therapeutic treatment for obesity and/or eating disorders. 


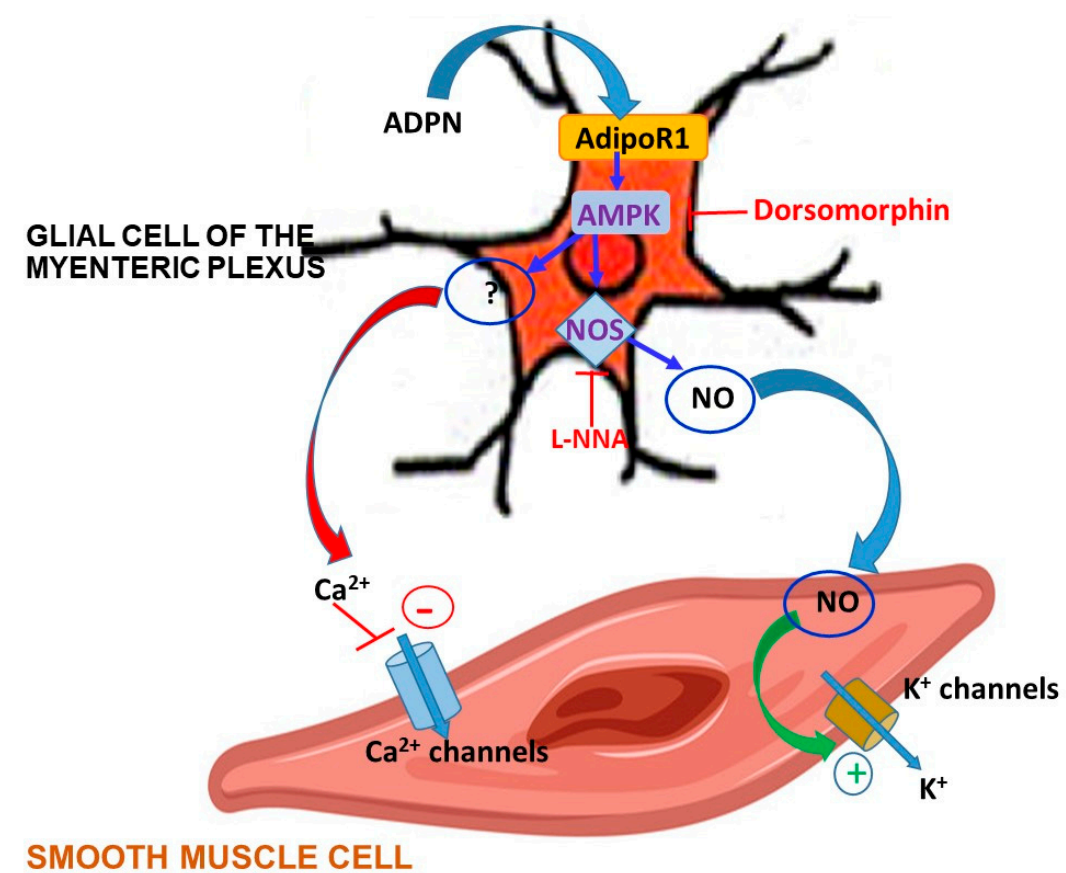

Figure 9. Schematic model depicting the putative action of ADPN on a glial cell of the myenteric plexus influencing SMC ion channels. ADPN interacts with AdipoR1 located on enteric glial cell membrane activating the AMPK pathway. This in turn promotes NOS activity, which leads to NO production. $\mathrm{NO}$, as a gaseous molecule, spreads to the nearby SMC, ultimately affecting its bioelectric properties. Particularly, $\mathrm{K}^{+}$channel activation results enhanced $(+)$, whereas the $\mathrm{Ca}^{2+}$ channel activation results decreased (-) by ADPN. However, the modulation of $\mathrm{Ca}^{2+}$ channels may not be due only to NO but can involve further downstream effectors to AMPK (as indicated by the question mark). The blockade of AMPK by dorsomorphin and the inhibition of NO synthesis by L-NNA are also illustrated in the scheme.

\section{Materials and Methods}

\subsection{Ethical Approval}

The experimental protocol was designed in compliance with the guidelines of the European Communities Council Directive 2010/63/UE and the recommendations for the care and use of laboratory animals approved by the Animal Care Committee of the University of Florence, Italy, with authorization from the Italian Ministry of Health nr. 787/2016-PR.

\subsection{Animals}

Experiments were performed on 8- to 12-week-old female mice (C57BL/6; Charles River, Lecco, Italy). The mice were fed standard laboratory chow and water and were housed under a 12-h light/12-h dark photoperiod and controlled temperature $\left(21 \pm 1^{\circ} \mathrm{C}\right)$. The mice were killed by prompt cervical dislocation to minimize animal suffering.

\subsection{Mechanical Experiments}

A previously reported $[5,38]$ full-thickness longitudinal strips were dissected from the stomach and mounted in 5-mL organ baths containing Krebs-Henseleit solution composed of $118 \mathrm{mM} \mathrm{NaCl}, 4.7 \mathrm{mM}$ $\mathrm{KCl}, 1.2 \mathrm{mM} \mathrm{MgSO}_{4}, 1.2 \mathrm{mM} \mathrm{KH}_{2} \mathrm{PO}_{4}, 25 \mathrm{mM} \mathrm{NaHCO}_{3}, 2.5 \mathrm{mM} \mathrm{CaCl}_{2}$, and $10 \mathrm{mM}$ glucose (pH 7.4) and bubbled with $95 \% \mathrm{O}_{2}-5 \% \mathrm{CO}_{2}$. The temperature was maintained within a range of $37 \pm 0.5^{\circ} \mathrm{C}$. One end of each preparation was tied to a platinum rod, and the other was connected to a force displacement transducer (FT03; Grass Instruments, Quincy, MA, USA) by a silk thread for continuous 
recording of isometric tension. The transducer was coupled to a polygraph (7 K; Grass Instruments). Preparations were allowed to equilibrate for $1 \mathrm{~h}$ under an initial load of $0.8 \mathrm{~g}$. During this period, the preparations underwent repeated and prolonged washes with Krebs-Henseleit solution to prevent accumulation of metabolites in the organ baths.

All functional experiments were carried out in the presence of $1 \mu \mathrm{M}$ guanethidine sulfate and $1 \mu \mathrm{M}$ carbachol (CCh) to rule out the adrenergic and the cholinergic influences, respectively. When contraction elicited by $\mathrm{CCh}$ reached a stable plateau phase, ADPN or drugs were applied. The interval between two subsequent applications of CCh was no less than $30 \mathrm{~min}$, during which repeated and prolonged washes of the preparations with Krebs-Henseleit solution were performed. The effects of ADPN $(20 \mathrm{nM})$ were investigated alone as well as $15 \mathrm{~min}$ following the addition of TTX or L-NG-nitro arginine (L-NNA) to the bath medium.

\subsection{Electrophysiological Experiments}

For electrophysiological recordings, the stomach was quickly removed and cleaned with Krebs-Henseleit solution as reported previously [5,6], which consisted of $118 \mathrm{mM} \mathrm{NaCl}, 4.7 \mathrm{mM} \mathrm{KCl}$, $1.2 \mathrm{mM} \mathrm{MgSO}_{4}, 1.2 \mathrm{mM} \mathrm{KH}_{2} \mathrm{PO}_{4}, 25 \mathrm{mM} \mathrm{NaHCO}_{3}, 2.5 \mathrm{mM} \mathrm{CaCl}_{2}$, and $10 \mathrm{mM}$ glucose (pH 7.4). At least two strips of gastric fundus were obtained from each stomach. A full-thickness strip was cut and pinned to a Sylgard (Dow Corning, Midland, MI, USA)-coated dissecting Petri dish filled with Krebs-Henseleit solution. First, we pinned the mucosal side up to dissect carefully the mucosa and submucosa away under a dissecting microscope. The residual tissue was re-pinned serosal side up, and the connective tissue was removed in order to expose the smooth muscle layer. The obtained tissue was finally pinned, serosal side up, in the recording chamber with a Sylgard floor. During the experiments, the tissue was continuously superfused (Pump 33, Harvard Apparatus, Holliston, MA, 01746, United States) at a rate of $1.8 \mathrm{~mL}$ min-1 with Krebs-Henseleit solution. Intracellular recording was made by a conventional high resistance glass microelectrode [28] inserted in a cell of the longitudinal smooth muscle layer (SMC). Microelectrodes were obtained by using a micropipette vertical puller (Narishige PC-10) from borosilicate glass (GC 100-7.5; Clark, Reading, UK) and were normally filled with the following internal solution (mM): $\mathrm{KCl} 130, \mathrm{NaH}_{2} \mathrm{PO}_{4} 10, \mathrm{CaCl}_{2}$ 0.2, ethylene-bis(oxyethylenenitrilo) tetraacetic acid (EGTA) 1, MgATP 5 and 4-(2-hydroxyethyl)-1-piperazineethanesulfonic acid (HEPES)/KOH 10. Once filled, the pipette resistance measured $60-70 \mathrm{M} \Omega$. The $\mathrm{pH}$ was set to 7.4 with $\mathrm{NaOH}$ and to 7.2 with tetraethylammonium hydroxide (TEA-OH) for bath and pipette solution, respectively. For RMP recording in current-clamp experiments, we used Krebs-Henseleit as the control bath solution. The delayed rectifier $\mathrm{K}^{+}$current records were achieved in voltage-clamp condition using a modified Krebs-Henseleit solution with different specific channels blockers added: $\mathrm{BaCl}_{2}$ to block the inward rectifier $\mathrm{K}^{+}$current, $\mathrm{I}_{\mathrm{Kir}}$, nifedipine to block L-type $\mathrm{Ca}^{2+}$ current, TTX to block $\mathrm{Na}^{+}$current, 4 -aminopyridine (4-AP) to block transient outward $\mathrm{K}^{+}$current $\left(\mathrm{I}_{\mathrm{to}}\right)$. The type of voltage-dependent delayed rectifier current involved in the total outward $\mathrm{K}^{+}$records was evaluated by pharmacological dissection $[28,49,50]$. Accordingly, three types of delayed rectifier currents, $\mathrm{I}_{\mathrm{BK}}, \mathrm{I}_{\mathrm{Ks}}$, and $\mathrm{I}_{\mathrm{Kv}}$ were identified by the following specific blockers: iberiotoxin (IbTx), chromanol (Chr) and $\alpha$-dendrotoxin $(\alpha$-DTX), respectively.

To record only $\mathrm{Ca}^{2+}$ currents, the microelectrodes were filled with the following filling electrode solution (mM): $150 \mathrm{CsBr}, 5 \mathrm{MgCl}_{2}$, 10 ethylene-bis(oxyethylenenitrilo) tetraacetic acid (EGTA), 10 (4-(2-hydroxyethyl)-1-piperazineethanesulfonic acid) (HEPES). Moreover, we used a $\mathrm{Na}^{+}$- and $\mathrm{K}^{+}$-free high-TEA external solution with the following composition (mM): $10 \mathrm{CaCl}_{2}, 145 \mathrm{TEABr}$ and 10 HEPES. Nifedipine was used to test $\mathrm{I}_{\mathrm{Ca}, \mathrm{L}}$ occurrence.

The gap junctional blocker heptanol $(1 \mathrm{mM})$ was added to any bath solution to avoid electrical coupling among the SMCs and to enable the recording of any phenomena elicited only from the impaled cell $[6,49,51,52]$. 
Any current amplitude was normalized to cell linear capacitance $\mathrm{Cm}$ to consent the evaluation of test current recorded from cells of different size; in fact, $\mathrm{Cm}$ is usually considered an index of cell-surface area, presuming that the membrane-specific capacitance has a constant value of $1 \mu \mathrm{F} / \mathrm{cm}^{2}$.

\section{Pulse Protocols of Stimulation}

We recorded the RMP of the SMCs before and after drug stimulation by using the current clamp mode of our amplifier with a stimulus waveform: $\mathrm{I}=0 \mathrm{pA}$. The membrane passive properties ( $\mathrm{Rm}, \mathrm{Gm}$ and $\mathrm{Cm}$ ) were consistently estimated by applying two step voltage pulses $75 \mathrm{~ms}$ long to -80 and $-60 \mathrm{mV}$ starting from a holding potential (HP) of $-70 \mathrm{mV}$, in voltage clamp condition. Always in this mode, ionic currents were evoked by the following pulse protocols: outward $\mathrm{K}^{+}$current activation was elicited by 1-s long voltage step pulses ranging from -80 to $50 \mathrm{mV}$ applied in $10-\mathrm{mV}$ increments from $\mathrm{HP}=-60 \mathrm{mV} . \mathrm{Ca}^{2+}$ current $\left(\mathrm{I}_{\mathrm{Ca}}\right)$ activation was evoked in the SMCs held at $-80 \mathrm{mV}$, and 1-s long step pulses were applied in 10-mV increments from -70 to $50 \mathrm{mV}$; an interval of $20 \mathrm{~s}$ between episodes was given to allow recovery. $\mathrm{I}_{\mathrm{Ca}}$ inactivation was investigated by a two-pulse protocol with a 1-s pre-pulse to different voltages followed by 1-s test pulse to $10 \mathrm{mV}$ [28]. When we applied the two-pulse protocol, we used again a 20-s interval between stimulating episodes to consent to recovery. Capacitive, linear leak, and voltage-independent ionic currents were cancelled on-line using the $\mathrm{P} / 4$ procedure.

To evaluate the steady-state ionic current activation of voltage dependent channels, we used the following equation:

$$
\operatorname{Ia}(V)=\operatorname{Gmax}(V-V r e v) /\{1+\exp [(V a-V) / k a]\}
$$

and the following was used for the steady-state current inactivation:

$$
\operatorname{Ih}(V)=I /\{1+\exp [-(V h-V) / k h]\},
$$

where Gmax represents the maximal conductance for Ia; Vrev is the apparent reversal potential; $V a$ and $V h$ are the voltages causing the half-maximal activation and inactivation, respectively; and $k a$ and $k h$ are steepness factors of activation and inactivation, respectively.

\subsection{Western Blotting}

Fragments of gastric fundus from the control and the ADPN-treated mice were quickly minced and homogenized with a tissue homogenizer (Ing. Terzano, Milan, Italy) in cold lysis buffer of the following composition: $20 \mathrm{mM}$ Tris/ $\mathrm{HCl}$ (pH 7.4), $10 \mathrm{mM} \mathrm{NaCl}, 1.5 \mathrm{mM} \mathrm{MgCl}_{2}, 5 \mathrm{mM}$ EGTA, 2 mM Na 2 EDTA, added with 10× Sigmafast Protease Inhibitor Cocktail tablets and $100 \mathrm{mM}$ sodium orthovanadate. Total protein content was measured spectrophotometrically using micro-BCA ${ }^{\mathrm{TM}}$ Protein Assay Kit (Pierce, IL, USA). Seventy $\mu \mathrm{g}$ of total proteins were electrophoresed by SDS-PAGE and blotted onto PVDF membranes (Millipore, Bedford, MA, USA). The membranes were incubated overnight at $4{ }^{\circ} \mathrm{C}$ with the following primary antibodies: rabbit polyclonal anti-AMPK (1: 1000; Cell Signaling, Danvers, MA, USA), rabbit polyclonal anti phosphoAMPK (Thr172), (pAMPK) (1:1000; Cell Signaling), and rabbit polyclonal anti- $\beta$-actin (1:20,000; Sigma Aldrich, Milan, Italy), assuming $\beta$-actin as control invariant protein. Specific bands were detected using rabbit peroxidase-labeled secondary antibodies (1:15.000 Vector, Burlingame, CA, USA) and enhanced chemiluminescent substrate. Densitometric analysis of the bands was performed using Scion Image Beta 4.0.2 image analysis software (Scion Corp., Frederick, MD, USA).

\subsection{Immunofluorescence Analysis}

Gastric tissue samples were rapidly excised and fixed by immersion in $4 \%$ paraformaldehyde, dehydrated in graded ethanol, embedded in paraffin, and cut in $5-\mu \mathrm{m}$ thick sections. To evaluate AdipoR1 expression, double labeling immunofluorescence experiments were performed. The sections were deparaffinized, rehydrated, and boiled for $10 \mathrm{~min}$ in sodium citrate buffer $(10 \mathrm{mM}, \mathrm{pH}$ 6.0, 
Bio-Optica, Milan, Italy) for antigen retrieval. To quench autofluorescence caused by the elastic fibers, the sections were incubated in $2 \mathrm{mg} / \mathrm{mL}$ glycine (AppliChem, Darmstadt, Germany) for $8 \mathrm{~min}$ at room temperature (RT). To minimize the unspecific binding, the sections were pre-incubated with $1.5 \%$ bovine serum albumin (Sigma Aldrich) for $20 \mathrm{~min}$ at RT and then incubated overnight at $4{ }^{\circ} \mathrm{C}$ with rabbit monoclonal anti-AdipoR1 antibody (1:400, Abcam, Milan, Italy) followed by goat anti-rabbit Alexa Fluor 488-conjugated IgG (1:350 Invitrogen, San Diego, CA, USA), for $2 \mathrm{~h}$ at RT. After the first incubation as described above, the sections were re-incubated overnight at $4{ }^{\circ} \mathrm{C}$ with goat polyclonal anti- $\alpha$ SMA (smooth muscle cell marker) antibody (1:200; Abcam), or with mouse monoclonal anti-UCH-L1 (neuronal marker) antibody (1:200; Santa Cruz Biotechnology, Texas, USA), or with chicken polyclonal anti-GFAP (glial cell marker) antibody (1: 500; Abcam). Then, the sections were incubated with the appropriate Alexa Fluor 568-conjugated IgG (1:350; Invitrogen) for $2 \mathrm{~h}$ at RT. To evaluate AMPK and pAMPK expression, gastric tissue sections from control and ADPN-treated mice were processed as above and incubated overnight at $4{ }^{\circ} \mathrm{C}$ with rabbit polyclonal anti-pAMPK antibody (1:50, Cell signaling) or rabbit polyclonal anti-AMPK (1:50; Cell Signaling) followed by goat anti-rabbit Alexa Fluor 488-conjugated IgG (1:175 Invitrogen) for $2 \mathrm{~h}$ at RT. After the first incubation, the sections were re-incubated overnight at $4{ }^{\circ} \mathrm{C}$ with chicken polyclonal anti-GFAP antibody (1: 500; Abcam), followed by donkey anti-chicken Alexa Fluor 568-conjugated IgG (1:350; Invitrogen) for $2 \mathrm{~h}$ at RT. Negative controls were performed by omitting the primary antibodies. The sections were mounted with Fluoroshied ${ }^{\mathrm{TM}}$ mounting medium containing the nuclear marker DAPI (Sigma Aldrich). Images were obtained using an epi-fluorescence Olympus BX40 microscope coupled to analySIS $\wedge$ B Imaging Software (Olympus, Milan, Italy) with 60× objectives.

\subsection{Data Analysis and Statistical Tests}

For functional experiments, amplitude of the responses is expressed as absolute values (grams) and measured when the maximal effect was reached. Basal tension was evaluated as changes in the recording baseline.

For electrophysiological experiments, mathematical and statistical analysis of data was performed by pClamp6 (Axon Instruments) and Excel (Microsoft Office 2016, Microsoft corporation, Redmond, WA, USA). Data are collected from a representative, randomly selected portion of the total cell populations and the results of the experiments are expressed as mean $\pm \mathrm{SD}$.

Student's unpaired t-test was used to compare the average values of two datasets, assuming that values follow a normal distribution. One-way ANOVA was used for multiple comparisons followed by Bonferroni's post hoc analysis. Statistical significance was set to $p<0.05$. The number of muscle preparations/cells was designated by $n$.

\subsection{Drugs}

The following drugs were used: $\alpha$-dendrotoxin ( $\alpha$-DTX, $10 \mathrm{nM}$ ); 4-aminopyridine (4-AP, $2 \mathrm{mM})$; barium chloride $\left(\mathrm{BaCl}_{2}, 0.4 \mathrm{mM}\right)$; chromanol $(\mathrm{Chr}, 50 \mu \mathrm{M})$; iberiotoxin $(\mathrm{IbTx}, 100 \mathrm{nM})$; mouse recombinant adiponectin (ADPN, $20 \mathrm{nM})$; nifedipine $(10 \mu \mathrm{M})$; tetrodotoxin (TTX, $1 \mu \mathrm{M})$, carbachol (CCh, $1 \mu \mathrm{M})$, guanethidine $(1 \mu \mathrm{M})$, L-NG-nitro arginine (L-NNA, $200 \mu \mathrm{M})$, dorsomorphin, $(10 \mu \mathrm{M})$. All drugs were obtained from Sigma Chemical (St. Louis, MO, USA).

Solutions were prepared on the day of the experiment, except for TTX and ADPN, for which stock solutions were kept stored at $-20^{\circ} \mathrm{C}$.

Drug concentrations are referred as final bath concentrations. The chosen dose of ADPN is that previously reported to be effective in gastric preparations $[5,6]$.

Author Contributions: Conceptualization, R.S., G.C. and M.C.B.; methodology, E.I., R.G., A.D. and S.N.; software, E.I., R.S.; validation, R.S., G.C., V.R. and M.C.B.; formal analysis, E.I. and R.S., E.C., E.R.; investigation, E.I., R.G., R.S., A.D., S.N.; resources, R.S. and M.C.B.; data curation, E.I., R.G., A.D. and S.N.; writing-original draft preparation, E.I.; writing-review and editing, R.S. and M.C.B.; visualization, S.N., G.C., V.R.; supervision, R.S. and M.C.B.; project administration, R.S. and M.C.B.; funding acquisition, R.S., G.C. and M.C.B. All authors have read and agreed to the published version of the manuscript. 
Funding: This research was funded by the University of Florence ATENEO RTD (CO 090101010107-SQUECCO_RICTD16) to RS and GC, RICATEN14 and Fondazione CRF (No. 2017.0777 and No.2018.0994) to MCB.

Acknowledgments: We wish to thank Fabio Francini, for his valuable contribution to electrophysiological data analysis and Claudio Pregno for preparation of the Figure 1. Thanks are due to Stefano Catarinicchia for skillful technical support in tissue sample preparation for immunofluorescence analysis.

Conflicts of Interest: The authors declare that the submitted work was carried out in the absence of any personal, professional or financial relationships that could potentially be construed as a conflict of interest.

\section{Abbreviations}

$\begin{array}{ll}\text { ADPN } & \text { Adiponectin } \\ \mathrm{C}_{\mathrm{m}} & \text { Cell linear capacitance } \\ \mathrm{CTRL} & \text { Control } \\ \mathrm{G}_{\mathrm{m}} & \text { Membrane conductance } \\ \mathrm{G}_{\mathrm{m}} / \mathrm{C}_{\mathrm{m}} & \text { Specific membrane conductance } \\ \mathrm{HP} & \text { Holding potential } \\ \mathrm{k}_{\mathrm{a}} & \text { Steepness factor of activation } \\ \mathrm{k}_{\mathrm{h}} & \text { Steepness factor of inactivation } \\ \mathrm{I}_{\mathrm{a}} & \text { Current activation } \\ \mathrm{I}_{\mathrm{Ca}} & \text { Ca } \\ \mathrm{I}_{\mathrm{K}} & \text { Voltage-dependent delayed rectifier } \mathrm{K}^{+} \text {currents } \\ \mathrm{RMP} & \text { Resting membrane potential } \\ \mathrm{SMC} & \text { Smooth muscle cell } \\ \mathrm{V}_{\mathrm{a}} & \text { Half-maximal activation voltage } \\ \mathrm{V}_{\mathrm{h}} & \text { Half-maximal inactivation voltage } \\ \mathrm{V}_{\mathrm{rev}} & \text { Apparent reversal potential }\end{array}$

\section{References}

1. Fasshauer, M.; Blüher, M. Adipokines in health and disease. Trends Pharmacol. Sci. 2015, 36, 461-470. [CrossRef]

2. Choi, H.M.; Doss, H.M.; Kim, K.S. Multifaceted Physiological Roles of Adiponectin in Inflammation and Diseases. Int. J. Mol. Sci. 2020, 21, 1219. [CrossRef]

3. Idrizaj, E.; Garella, R.; Squecco, R.; Baccari, M.C. Adipocytes-released Peptides Involved in the Control of Gastrointestinal Motility. Curr. Protein Pept. Sci. 2019, 20, 614-629. [CrossRef]

4. Camilleri, M. Peripheral mechanisms in appetite regulation. Gastroenterology 2015, 148, 1219-1233. [CrossRef]

5. Idrizaj, E.; Garella, R.; Castellini, G.; Mohr, H.; Pellegata, N.S.; Francini, F.; Ricca, V.; Squecco, R.; Baccari, M.C. Adiponectin affects the mechanical responses in strips from the mouse gastric fundus. World J. Gastroenterol. 2018, 24, 4028-4035. [CrossRef]

6. Idrizaj, E.; Garella, R.; Castellini, G.; Francini, F.; Ricca, V.; Baccari, M.C.; Squecco, R. Adiponectin Decreases Gastric Smooth Muscle Cell Excitability in Mice. Front. Physiol. 2019, 10, 1000. [CrossRef]

7. Bova, S.; Cavalli, M.; Cima, L.; Luciani, S.; Saponara, S.; Sgaragli, G.; Cargnelli, G.; Fusi, F. Relaxant and Ca ${ }^{2+}$ channel blocking properties of norbormide on rat non-vascular smooth muscles. Eur. J. Pharmacol. 2003, 470, 185-191. [CrossRef]

8. Si, X.; Huang, L.; Luo, H.; Shi, R. Inhibitory effects of somatostatin on cholecystokinin octapeptide induced bile regurgitation under stress: Ionic and molecular mechanisms. Regul. Pept. 2009, 156, 34-41. [CrossRef]

9. Zhang, S.Y.; Cai, Z.X.; Li, P.; Cai, C.Y.; Qu, C.L.; Guo, H.S. Effect of dendroaspis natriuretic peptide (DNP) on L-type calcium channel current and its pathway. Regul. Pept. 2010, 164, 120-125. [CrossRef]

10. Rich, A.; Kenyon, J.L.; Hume, J.R.; Overtuf, K.; Horowitz, B.; Sanders, K.M. Dihydropyridine-sensitive calcium channels expressed in canine colonic smooth muscle cells. Am. J. Physiol. 1993, C745-C754. [CrossRef]

11. Kovac, J.R.; Preiksaitis, H.G.; Sims, S.M. Functional and molecular analysis of L-type calcium channels in human esophagus and lower esophageal sphincter smooth muscle. Am. J. Physiol. Gastrointest. Liver Physiol. 2005, 289, G998-G1006. [CrossRef] 
12. Xiong, Z.; Sperelakis, N.; Noffsinger, A.; Fenoglio-Preiser, C. $\mathrm{Ca}^{2+}$ currents in human colonic smooth muscle cells. Am. J. Physiol. 1995, 269, G378-G385. [CrossRef]

13. Hart, P.J.; Overturf, K.E.; Russell, S.N.; Carl, A.; Hume, J.R.; Sanders, K.M.; Horowitz, B. Cloning and expression of a Kv1.2 class delayed rectifier $\mathrm{K}^{+}$channel from canine colonic smooth muscle. Proc. Natl. Acad. Sci. USA 1993, 90, 9659-9663. [CrossRef]

14. Overturf, K.E.; Russel, S.N.; Carl, A.; Vogalis, F.; Hart, P.J.; Hume, J.R.; Sanders, K.M.; Horowitz, B. Cloning and characterization of a Kv1.5 delayed rectifier $\mathrm{K}^{+}$channel from vascular and visceral smooth muscles. Am. J. Physiol. 1994, C1231-C1238. [CrossRef]

15. Schmalz, F.; Kinsella, J.; Koh, S.D.; Vogalis, F.; Schneider, A.; Flynn, E.R.; Kenyon, J.L.; Horowitz, B. Molecular identification of a component of delayed rectifier current in gastrointestinal smooth muscle. Am. J. Physiol. 1998, 274, G901-G911. [CrossRef]

16. Koh, S.D.; Ward, S.M.; Dick, G.M.; Epperson, A.; Bonner, H.P.; Sanders, K.M.; Horowitz, B.; Kenyon, J.L. Contribution of delayed rectifier potassium currents to the electrical activity of murine colonic smooth muscle. J. Physiol. 1999, 515, 475-487. [CrossRef]

17. Benham, C.D.; Bolton, T.D.; Lang, R.J.; Takewaki, T. The mechanism of action of $\mathrm{Ba}^{2+}$ and TEA on single $\mathrm{Ca}^{2+}$-activated $\mathrm{K}^{+}$-channels in arterial and intestinal smooth muscle cell membranes. Pflügers Arch. 1985, 403, 120-127. [CrossRef]

18. Carl, A.; Sanders, K.M. Ca ${ }^{2+}$-activated K channels of canine colonic myocytes. Am. J. Physiol. 1989, 257, C470-C480. [CrossRef]

19. Vogalis, F.; Goyal, R.K. Activation of small conductance $\mathrm{Ca}^{2+}$-dependent $\mathrm{K}^{+}$channels by purinergic agonists in smooth muscle cells of the mouse ileum. J. Physiol. 1997, 502, 497-508. [CrossRef]

20. Koh, S.D.; Dick, G.M.; Sanders, K.M. Small-conductance $\mathrm{Ca}^{2+}$ dependent $\mathrm{K}^{+}$channels activated by ATP in murine colonic smooth muscle. Am. J. Physiol. 1997, 273, C2010-C2021. [CrossRef]

21. Kadowaki, T.; Yamauchi, T.; Kubota, N. The physiological and pathophysiological role of adiponectin and adiponectin receptors in the peripheral tissues and CNS. FEBS Lett. 2008, 582, 74-80. [CrossRef] [PubMed]

22. González, C.R.; Caminos, J.E.; Gallego, R.; Tovar, S.; Vázquez, M.J.; Garcés, M.F.; Lopez, M.; García-Caballero, T.; Tena-Sempere, M.; Nogueiras, R.; et al. Adiponectin receptor 2 is regulated by nutritional status, leptin and pregnancy in a tissue-specific manner. Physiol. Behav. 2010, 12, 91-99. [CrossRef] [PubMed]

23. Daisuke, N.; Yasunobu, H. The role of AMP-activated protein kinase in the cardiovascular system. Hypertens. Res. 2010, 33, 22-28. [CrossRef]

24. Musi, N.; Goodyear, L.J. Insulin resistance and improvements in signal transduction. Endocrine 2006, 29, 73-80. [CrossRef]

25. de Morentin, P.B.M.; Urisarri, A.; Couce, M.L.; López, M. Molecular mechanisms of appetite and obesity: A role for brain AMPK. Clin. Sci. 2016, 130, 1697-1709. [CrossRef] [PubMed]

26. Wang, B.; Cheng, K.K. Hypothalamic AMPK as a Mediator of Hormonal Regulation of Energy Balance. Int. J. Mol. Sci. 2018, 19, 3552. [CrossRef] [PubMed]

27. Coope, A.; Milanski, M.; Araújo, E.P.; Tambascia, M.; Saad, M.J.; Geloneze, B.; Velloso, L.A. AdipoR1mediates the anorexigenic and insulin/leptin-like actions of adiponectin in the hypothalamus. FEBS Lett. 2008, 582, 1471-1476. [CrossRef]

28. Squecco, R.; Garella, R.; Luciani, G.; Francini, F.; Baccari, M.C. Muscular effects of orexin A on the mouse duodenum: Mechanical and electrophysiological studies. J. Physiol. 2011, 589, 5231-5246. [CrossRef]

29. Lynch, F.M.; Withers, S.B.; Yao, Z.; Werner, M.E.; Edwards, G.; Weston, A.H.; Heagerty, A.M. Perivascular adipose tissue-derived adiponectin activates $\mathrm{BK}(\mathrm{Ca})$ channels to induce anticontractile responses. Am. J. Physiol. Heart Circ. Physiol. 2013, 304, H786-H795. [CrossRef]

30. Park, S.Y.; Choi, J.H.; Ryu, H.S.; Pak, Y.K.; Park, K.S.; Lee, H.K.; Lee, W. C1q tumor necrosis factor alpha-related protein isoform 5 is increased in mitochondrial DNA-depleted myocytes and activates AMP-activated protein kinase. J. Biol. Chem. 2009, 284, 27780-27789. [CrossRef] 
31. He, Y.; Liu, B.; Yao, P.; Shao, Y.; Cheng, Y.; Zhao, J.; Wu, J.; Zhao, Z.W.; Huang, W.; Christopher, T.A.; et al. Adiponectin inhibits cardiac arrest/cardiopulmonary resuscitation-induced apoptosis in brain by increasing autophagy involved in AdipoR1-AMPK signaling. Mol. Med. Rep. 2020, 22, 870-878. [CrossRef] [PubMed]

32. Niemann, B.; Li, L.; Siegler, D.; Siegler, B.H.; Knapp, F.; Hanna, J.; Aslam, M.; Kracht, M.; Schulz, R.; Rohrbach, S. CTRP9 Mediates Protective Effects in Cardiomyocytes via AMPK- and Adiponectin Receptor-Mediated Induction of Anti-Oxidant Response. Cells 2020, 9, 1229. [CrossRef] [PubMed]

33. Pal, S.; Porwal, K.; Rajak, S.; Sinha, R.A.; Chattopadhyay, N. Selective dietary polyphenols induce differentiation of human osteoblasts by adiponectin receptor 1-mediated reprogramming of mitochondrial energy metabolism. Biomed. Pharmacother. 2020, 127, 110207. [CrossRef] [PubMed]

34. Chen, H.; Montagani, M.; Funahashi, T.; Shimimura, L.; Quon, M.J. Adiponectin stimulates production of nitric oxid in vascular endothelial cells. J. Biol. Chem. 2003, 278, 45021-45026. [CrossRef]

35. Han, G.; Ma, H.; Chintala, R.; Miyake, K.; Fulton, D.J.; Barman, S.A.; White, R.E. Nongenomic, endothelium-independent effects of estrogen on human coronary smooth muscle are mediated by type I (neuronal) NOS and PI3-kinase-Akt signaling. Am. J. Physiol. Heart Circ. Physiol. 2007, 293, H314-H321. [CrossRef]

36. Shin, M.J.; Lee, Y.P.; Kim, D.W.; An, J.J.; Jang, S.H.; Cho, S.M.; Sheen, S.H.; Lee, H.R.; Kweon, H.Y.; Kang, S.W.; et al. Transduced PEP-1-AMPK inhibits the LPS-induced expression of COX-2 and iNOS in Raw264.7 cells. BMB Rep. 2010, 43, 40-45. [CrossRef]

37. Squecco, R.; Garella, R.; Idrizaj, E.; Nistri, S.; Francini, F.; Baccari, M.C. Relaxin Affects smooth muscle biophysical properties and mechanical activity of the female mouse colon. Endocrinology 2015, 156, 4398-4410. [CrossRef]

38. Garella, R.; Idrizaj, E.; Traini, C.; Squecco, R.; Vannucchi, M.G.; Baccari, M.C. Glucagon-like peptide-2 modulates the nitrergic neurotransmission in strips from the mouse gastric fundus. World J. Gastroenterol. 2017, 23, 7211-7220. [CrossRef]

39. Nour-Eldine, W.; Ghantous, C.M.; Zibara, K.; Dib, L.; Issaa, H.; Itani, H.A.; El-Zein, N.; Zeidan, A. Adiponectin attuates angiotensin II- induced vascular smooth, muscle cell remodeling through nitric oxide and the Rhoa/ROCK pathway. Front. Pharmacol. 2016, 7, 86. [CrossRef]

40. Wang, Z.; Wu, Y.; Zhang, S.; Zhao, Y.; Yin, X.; Wang, W.; Ma, X.; Liu, H. The role of NO-cGMP pathway inhibition in vascular endothelial-dependent smooth muscle relaxation disorder of AT1-AA positive rats: Protective effects of adiponectin. Nitric Oxide 2019, 87, 10-22. [CrossRef]

41. Cersosimo, E.; Xu, X.; Terasawa, T.; Dong, L.Q. Anti-inflammatory and anti-proliferative action of adiponectin mediated by insulin signaling cascade in human vascular smooth muscle cells. Mol. Biol. Rep. 2020, 47, 6561-6572. [CrossRef] [PubMed]

42. Kadowaki, T.; Yamauchi, T. Adiponectin and Adiponectin Receptors. Endocr. Rev. 2005, 26, 439-451. [CrossRef] [PubMed]

43. Ahima, R.S. Adipose Tissue as an Endocrine Organ. Obesity 2006, 5, 242S-249S. [CrossRef] [PubMed]

44. Jeon, S.M. Regulation and function of AMPK in physiology and diseases. Exp. Mol. Med. 2016, 48, e245. [CrossRef] [PubMed]

45. Ruan, H.; Dong, L.Q. Adiponectin signaling and function in insulin target tissues. J. Mol. Cell Biol. 2016, 8, 101-109. [CrossRef]

46. Schneider, S.; Wright, C.M.; Heuckeroth, R.O. Unexpected Roles for the Second Brain: Enteric Nervous System as Master Regulator of Bowel Function. Annu. Rev. Physiol. 2019, 81, 235-259. [CrossRef]

47. Idrizaj, E.; Garella, R.; Squecco, R.; Baccari, M.C. Can adiponectin have an additional effect on the regulation of food intake by inducing gastric motor changes? World J. Gastroenterol. 2020, 26, 2472-2478. [CrossRef]

48. Duca, F.A.; Covasa, M. Current and emerging concepts on the role on peripheral signals in the control of food intake and development of obesity. Br. J. Nutr. 2012, 108, 778-793. [CrossRef]

49. Idrizaj, E.; Garella, R.; Francini, F.; Squecco, R.; Baccari, M.C. Relaxin influences ileal muscular activity through a dual signaling pathway in mice. World J. Gastroenterol. 2018, 24, 882-893. [CrossRef]

50. Baglioni, S.; Cantini, G.; Poli, G.; Francalanci, M.; Squecco, R.; Di Franco, A.; Borgogni, E.; Frontera, S.; Nesi, G.; Liotta, F.; et al. Functional differences in visceral and subcutaneous fat pads originate from differences in the adipose stem cell. PLoS ONE 2012, 7, e36569. [CrossRef] 
51. Squecco, R.; Sassoli, C.; Nuti, F.; Martinesi, M.; Chellini, F.; Nosi, D.; Zecchi-Orlandini, S.; Francini, F.; Formigli, L.; Meacci, E. Sphingosine 1-phosphate induces myoblast differentiation through Cx43 protein expression: A role for a gap junction-dependent and -independent function. Mol. Biol. Cell 2006, 17, 4896-4910. [CrossRef]

52. Formigli, L.; Sassoli, C.; Squecco, R.; Bini, F.; Martinesi, M.; Chellini, F.; Luciani, G.; Sbrana, F.; Zecchi-Orlandini, S.; Francini, F.; et al. Regulation of transient receptor potential canonical channel 1 (TRPC1) by sphingosine 1-phosphate in C2C12 myoblasts and its relevance for a role of mechanotransduction in skeletal muscle differentiation. J. Cell Sci. 2009, 122, 1322-1333. [CrossRef]

Publisher's Note: MDPI stays neutral with regard to jurisdictional claims in published maps and institutional affiliations.

(C) 2020 by the authors. Licensee MDPI, Basel, Switzerland. This article is an open access article distributed under the terms and conditions of the Creative Commons Attribution (CC BY) license (http://creativecommons.org/licenses/by/4.0/). 